\title{
Article \\ A Geospatial Approach to Energy Planning in Aid of Just Energy Transition in Small Island Communities in the Philippines
}

\author{
Khrisydel Rhea M. Supapo ${ }^{1,2, * \mathbb{D}}$, Lorafe Lozano ${ }^{1,3,4} \mathbb{D}$, Ian Dominic F. Tabañag ${ }^{1,5}$ and Edward M. Querikiol $1,3,6 \mathbb{D}$ \\ 1 Engineering Graduate Program, School of Engineering, University of San Carlos, Cebu City 6000, Philippines; \\ lflozano@usc.edu.ph (L.L.); iftabanag@usc.edu.ph (I.D.F.T.); emquerikiol@usc.edu.ph (E.M.Q.) \\ 2 Department of Electrical Engineering, Palawan State University, Puerto Princesa 5300, Philippines \\ 3 Center for Research in Energy Systems and Technologies, School of Engineering, University of San Carlos, \\ Cebu City 6000, Philippines \\ 4 Department of Industrial Engineering, University of San Carlos, Cebu City 6000, Philippines \\ 5 Department of Chemical Engineering, University of San Carlos, Cebu City 6000, Philippines \\ 6 Department of Electrical and Electronics Engineering, University of San Carlos, Cebu City 6000, Philippines \\ * Correspondence: krmsupapo@psu.palawan.edu.ph
}

check for

updates

Citation: Supapo, K.R.M.; Lozano,

L.; Tabañag, I.D.F.; Querikiol, E.M. A

Geospatial Approach to Energy

Planning in Aid of Just Energy

Transition in Small Island Communities

in the Philippines. Appl. Sci. 2021, 11,

11955. https://doi.org/10.3390/

app112411955

Academic Editor: Filippo Busato

Received: 9 November 2021

Accepted: 10 December 2021

Published: 15 December 2021

Publisher's Note: MDPI stays neutral with regard to jurisdictional claims in published maps and institutional affiliations.

Copyright: (c) 2021 by the authors. Licensee MDPI, Basel, Switzerland. This article is an open access article distributed under the terms and conditions of the Creative Commons Attribution (CC BY) license (https:// creativecommons.org/licenses/by/ $4.0 /)$.

\begin{abstract}
Providing electricity in off-grid island communities is a big challenge, exacerbated by the high cost of transporting fossil fuels and the non-viability of extending grid connections. Installing renewable energy systems in these areas is deemed a practical solution, especially supporting just energy transitions in these communities. However, the lack of information about resource availability and the most suitable locations hinders effective planning. This paper aims to determine the sufficiency of available renewable energy sources to meet the electricity demand of off-grid island communities. It is achieved through a three-phased approach: (1) an assessment stage; (2) geospatial analysis; and (3) technical potential estimation. The approach is applied in three island communities in Palawan, namely Araceli, Balabac, and Cuyo, where a diesel power plant currently provides electricity to its households and commercial/institutional establishments. The results indicate that the three islands can be powered by 3, 1.5, and 11 MW solar photovoltaic farms, respectively, which is sufficient to meet the projected demand until 2030. The approach can be helpful, especially for off-grid island communities, as they plan to provide universal electricity access using renewable energy sources.
\end{abstract}

Keywords: energy access; load forecasting; renewable energy; resource mapping; GIS; multicriteria decision analysis; analytic hierarchy process

\section{Introduction \\ 1.1. Background}

Since its commercialization, electricity has become a necessity, from lighting a small light bulb to cooling air conditioners during summer, heating electric heaters during winter, and powering industrial machinery. It plays a vital role when it comes to global economic development. The development of one country may become fast-paced because of its availability or may slow down due to the lack of it. There are various electricity generation sources, from non-renewable (coal, gas, nuclear, and oil) to renewable energy (RE) such as solar PV, hydro, and wind. Figure 1 shows the latest electricity generation mix worldwide [1], indicating that non-renewable resources are still the dominant sources of electricity. When these fuels are burned, they release carbon dioxide $\left(\mathrm{CO}_{2}\right)$ and other greenhouse gases (GHGs) that may trap heat in the atmosphere, resulting in climate change and global warming [2]. This prompted the United Nations to adopt the Sustainable Development Goals (SDG) in 2015, which provides a roadmap for climate actions to reduce GHG emissions and build climate resilience [3]. Since coal-fired power generation is the 
biggest emitter of all energy-related $\mathrm{CO}_{2}$ emissions [4], most countries have already started using renewable energy technologies (RETs), which helped to decrease the global $\mathrm{CO}_{2}$ emissions by almost $8 \%$ in 2019 . The share of renewables in the electricity generation mix rose considerably with the additional output of new wind and solar projects completed over the past year [5].

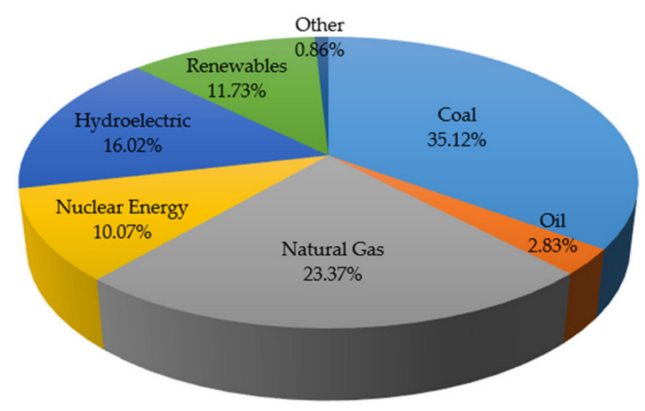

Figure 1. World electricity generation mix by source.

The archipelagic nature of the Philippines proves to be a challenge in achieving universal electricity access and just transition, especially in off-grid communities, where grid extension is unviable, and diesel generator sets are the typical sources of energy. The Department of Energy (DOE) created an energy plan to secure the country's energy future and to actively promote the use of indigenous renewable resources [6] to expand energy access for remote and off-grid areas that are not reached by the primary grid and achieve $100 \%$ electrification by 2022 [7]. As of the 2018 World Bank report, $94.9 \%$ of the country's population has electricity access, with the remaining $5.1 \%$ who do not have access living mostly in remote island communities [8]. These island communities do not have grid access and are powered by diesel generators with a time-limited supply, translating to high electricity costs [9]. Solar, biomass, and wind resources are abundantly available as local energy sources on most small islands, making RETs or hybrid renewable energy systems (HRES) a practical approach to electrifying these communities.

Geospatial analysis has gained much attention in the past few years when it comes to identifying RE resources. Typical studies evaluate suitable locations for the development of RETs [10-14], site selection [15], and residential building energy demand and performance $[16,17]$. RE resource mapping can help the Philippines plan for energy access and just transition, especially in off-grid island communities. However, there is a need to streamline the RE resource mapping approach to consider consumption patterns such that initiatives for a cleaner energy transition ensure that electricity demands are met. The goal of this paper is to determine if renewable energy sources available in off-grid island communities are sufficient to meet the electricity demand not only at the household level but also at the commercial and institutional levels. It is achieved through a three-phased approach, where the first phase is the assessment stage, including site and load profile studies to assess the current energy situation of the research areas and to project the electric load demand for up to the year 2030. The second phase is the geospatial analysis, which involves identifying the factors that affect the choice of suitable locations for installing renewable energy technologies. In this stage, possible locations for RE resources available in the study area were mapped, and the number of possible sites was identified. The third phase is the technical potential estimation to determine the available generated capacity of $\mathrm{RE}$ resources and its ability to meet forecasted demand.

The structure of this paper is as follows: Section 1.2 summarizes the literature review, discussing the strategies and plans of different countries, especially the Philippines, in the transition to cleaner energy. It also discusses the role of GIS in renewable energy planning and reviews the literature identifying the relevant and restrictive factors that influence site selection in terms of environmental, technical, technological, and socio-economic impacts. Section 2 illustrates the proposed framework, and Section 3 presents the methodology 
showing each stage of the three-phased approach as it is carried out. Section 4 presents the results, and Section 4 presents the discussion, concludes this study, and identifies the gaps for future studies.

\subsection{Literature Review}

Coal-fired power generation is the largest source of electricity globally and the biggest emitter of all energy-related $\mathrm{CO}_{2}$ emissions [4]. It prompted countries to adopt the goal of providing affordable, reliable, and clean energy for all [18]. Decarbonizing the power sector aims to achieve a zero-carbon world by increasing the deployment of RE systems to address energy demand [19]. RE is now considered a practical solution for greener energy and sustainable development, prompting most countries to transition from conventional fossil fuels to RE [20-23]. The archipelagic nature of the Philippines makes RE implementation more convenient, where small islands can obtain increased electricity access and cleaner electricity generation with RE implementation. However, the intermittence of RE supply, particularly solar energy resources, is thought to be unable to meet the demand consistently. It necessitates careful planning and resource identification in small island communities to ensure that RE supply is capable of meeting energy demand.

In recent years, the geographic information system (GIS) has grown in popularity as a tool for various site selection studies, particularly renewable energy planning [24]. There are several advantages when GIS is integrated with energy planning. One advantage is using spatial data to analyze demand in a particular location while creating forecasts that consider the location's unique characteristics and related energy access targets [25-27]. Likewise, GIS can assess renewable resource availability and energy potentials [28-30], finding the best suitable location for future energy infrastructure projects [31,32], and mapping out the existing transmission lines, distribution networks, etc. [33,34]. Using GIS in energy planning may help to avoid the sensitive areas that can cause adverse environmental and social impacts [35,36].

GIS plays a significant role in energy planning, from exploring renewable resources and combining them with the existing system to identifying a suitable site for the system installation. Most researchers have proposed integration methods combining GIS with other techniques to improve the potential assessment accuracy and increase site selection precision [37-39]. When combined with multicriteria decision-making (MCDM) methods, these can be among the most effective methods for locating potential renewable energy project sites [12]. They handle the process of making decisions where multiple objectives are considered [40]. The application of MCDM methods used several techniques in many kinds of research [41-43]. Ref. [44] reviewed the previous literature from 2009 to 2018, and among them, the analytic hierarchy process (AHP) ranked first as the most employed MCDM method. It has been used frequently to solve complex decision problems by using pairwise comparisons of criteria to reduce bias in decision-making $[45,46]$.

AHP can also be combined with other MCDM methods such as the Technique for Order Preference by Similarity to Ideal Solution (TOPSIS) [47-49]. The results provided by AHP can be further enhanced by using TOPSIS [50]. It is widely used and can effectively rank feasible sites from best to worst [51]. It proposes an optimal alternative from a series of alternatives with the shortest geometric distance from the positive ideal solution [50]. This hybrid MCDM method enables a more reliable geospatial analysis for electrification planning and site selection.

Table S1 [52-99] summarizes research from 2017 to 2021 using GIS with different RETs and applications used in electrification planning, while Figure 2 shows the percentage of each technology being studied. 


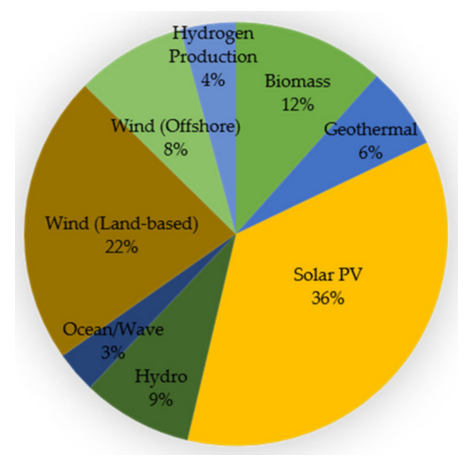

Figure 2. Percentage of studies based on RETs.

The top three RETs that gained so much attention among researchers worldwide are solar PV (36\%), wind power (30\%), and biomass (12\%). Though solar PV is not the largest contributor among the renewables in the worldwide energy generation mix, the share of solar PV generation rose by $22 \%$ in 2019, surpassing bioenergy to become the third-largest renewable energy technology after hydropower and onshore wind [100]. This makes solar energy one of the most important renewable sources today [46], and thus one of the most well-studied resources.

Wind energy potential is also prevalently evaluated. The studies regarding wind energy potential have two application areas. One is onshore, and the other is offshore or floating. While most wind farms today are usually built onshore, research studies shifted their focus to offshore or floating wind turbines. A study in the Canary Islands compared the wind turbine size ( $5 \mathrm{MW}$ for offshore and $2 \mathrm{MW}$ for onshore), which generates the same amount of annual energy demand, and the total area $\left(180 \mathrm{~km}^{2}\right.$ for offshore and $500 \mathrm{~km}^{2}$ for onshore) occupied by offshore and onshore wind farms. The results show that offshore projects require fewer wind turbines and surface area than onshore developments. Offshore wind conditions are far better than onshore wind conditions (i.e., higher wind speed, less turbulence, etc.), but in terms of cost, offshore costs are more than twice the onshore costs [101].

From the literature, most studies focused on RE resource availability and energy potential, suitable locations for the energy infrastructure facility, and electric network design in urban and rural areas. However, few studied the RE potentials in remote islands where energy access is a significant challenge and whether such potentials can efficiently meet demand.

\section{Materials and Methods}

\subsection{Study Sites}

There were three selected areas in this study-two islands located in northern Palawan, Philippines, and one in the southern part (Figure 3).

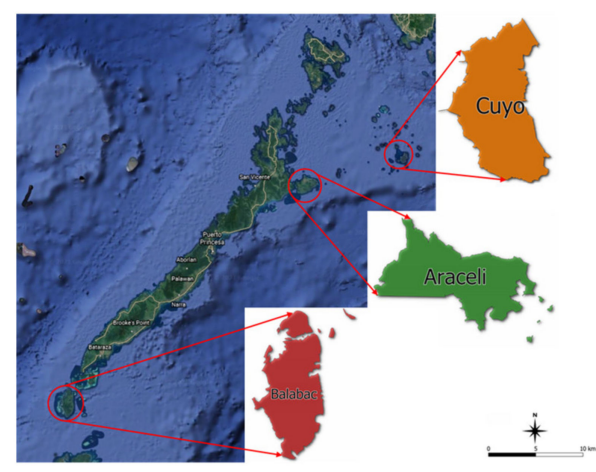

Figure 3. Map of the selected study areas. 
The first island is Araceli, a fourth-class municipality, and covers roughly the northern half of Dumaran Island. The second island is Cuyo, a coastal community found in the Sulu Sea $22.3 \mathrm{~m}$ above mean sea level [102]. The third study area is Balabac Island, located in the westernmost point in the Philippines. The site descriptions are summarized in Table 1.

Table 1. Site description of the selected areas [103,104].

\begin{tabular}{|c|c|c|c|c|c|c|}
\hline Study Area & Location & Area $\left(\mathbf{k m}^{2}\right)$ & Population & $\begin{array}{c}\text { No. of } \\
\text { Households }\end{array}$ & $\begin{array}{c}\text { Density } \\
\text { (Population/km²) }\end{array}$ & $\begin{array}{c}\text { No. of } \\
\text { Barangay }\end{array}$ \\
\hline Araceli & $\begin{array}{l}\text { Latitude: } 10^{\circ} 33^{\prime} 32^{\prime \prime} \mathrm{N} \\
\text { Longitude: } 119^{\circ} 59^{\prime} 40^{\prime \prime} \mathrm{E}\end{array}$ & 204.30 & 14,895 & 3294 & 73 & 13 \\
\hline Balabac & $\begin{array}{l}\text { Latitude: } 07^{\circ} 59^{\prime} \mathrm{N} \\
\text { Longitude: } 117^{\circ} 03^{\prime} \mathrm{E}\end{array}$ & 581.6 & 22,184 & 5103 & 69 & 20 \\
\hline Cuyo & $\begin{array}{l}\text { Latitude: } 10^{\circ} 51^{\prime} \mathrm{N} \\
\text { Longitude: } 121^{\circ} 01^{\prime} \mathrm{E}\end{array}$ & 84.95 & 39,853 & 8445 & 263 & 17 \\
\hline
\end{tabular}

\subsection{Data Collection and Georeferencing}

The data were collected from GIS public databases and local surveys, including exclusion layers, i.e., electric networks, roads, built-up areas, water bodies, and land use/land cover. All layers had their criteria based on the technology being mapped. The collected datasets were used to map solar energy potential. A digital elevation model (DEM) was obtained from the Shuttle Radar Topography Mission (SRTM) —Earthdata (NASA) in a raster format. It was then used to determine the slope and aspects essential in the site suitability analysis of solar energy. The slope and aspect were considered a critical topographical factor that significantly influences land suitability for installing PV systems, where it is best when it faces the south direction [105]. The reason is to avoid the shadow effect on the generation of the PV system [106]. Lands with a slope greater than $5^{\circ}$ were not considered [107], because it affects the reception of solar radiation, and the flatter the surface, the more radiation it received [108].

The wind speed is also an important parameter that influences land suitability for installing wind turbines. For the three study areas, the average annual wind speed at the height of $50 \mathrm{~m}$ is as follows: for Araceli, it is $5.82 \mathrm{~m} / \mathrm{s}$, for Balabac, it is $4.85 \mathrm{~m} / \mathrm{s}$, and for Cuyo, it its $6.39 \mathrm{~m} / \mathrm{s}$ [109]. Since Balabac did not meet the minimum criteria of $5.5 \mathrm{~m} / \mathrm{s}$ of mean wind speed, it was therefore excluded from the assessment.

\subsection{Research Framework}

The research framework is shown in Figure 4. The framework was developed based on a three-phased approach: (1) an assessment stage; (2) geospatial analysis; and (3) technical potential assessment. The assessment stage included study area investigation, load profile study, and load demand forecasting. The second approach involved the geospatial analysis using the GIS-MCDA method to map the available RE resources in the study areas. It also identified the factors that influence the selection of RE technologies' location. The third and final analysis estimated the technical potential of each RE resource. Then, these resources were evaluated to determine if the generated energy supply will be sufficient to meet the energy demand once it is fully utilized. The paper uses color convention: yellow represents "data", green means the "methods/analysis", blue is the "results of the assessment", and the "research approaches" are in orange. 


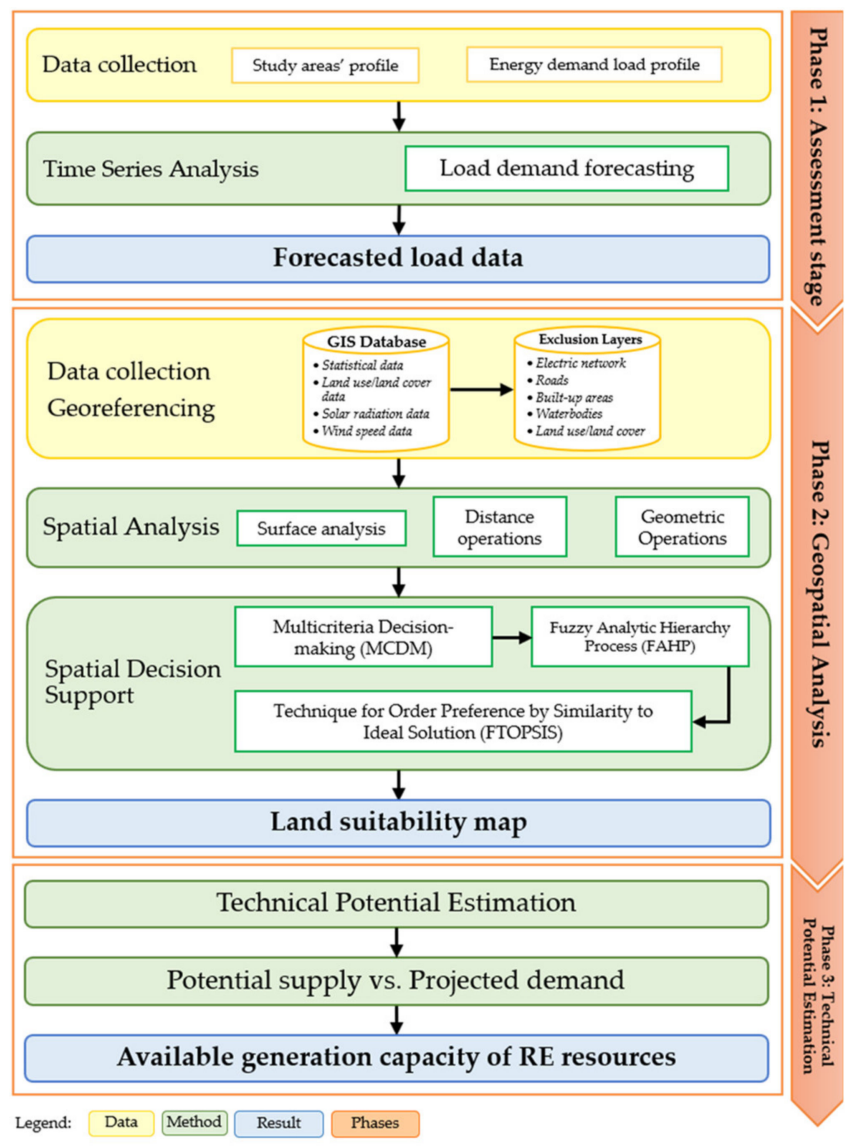

Figure 4. Research framework.

\subsubsection{Assessment Stage}

The assessment stage included (a) the identification of study areas, (b) the load profile study, and (c) load demand forecasting. The data were collected from local surveys and interviews. Other data, such as population and the number of households per barangay, were collected from the local government units. The load profile also came from the local distribution utility. The Holt-Winters exponential smoothing in R software was utilized to determine the forecast the load demand until 2030. It is known to be effective in forecasting seasonal time series, and the smoothing parameters were assumed to be $\alpha=0.2, \beta=0.1$, and $\gamma=0.2$, respectively [110]. While there are many advanced statistical methods to be used in forecasting and many parameters that need to be considered, this study used only one independent variable, i.e., historical load demand data. The forecasted load was compared with the result of resource mapping to determine whether the available generation potential from the available RE resources in the study areas will be sufficient to meet the current load demand until 2030.

\subsubsection{Geospatial Analysis}

The second approach was the geospatial analysis to map RE resources available in the study areas. It assessed environmental, technical, technological, and socio-economic factors. The determinant factors were used to identify the exclusion criteria and constraints for geospatial analysis that affect suitable locations for installing RE technologies. The methodology was based on the concept of the previous research [111].

\section{a. Spatial Analysis}

The geospatial analysis involves several methods such as surface analysis, geometric operations, and distance operations. As shown in Table 2 below, the exclusion criteria and constraints were applied regarding environmental, technical, technological, and socio- 
economic aspects. The specific reclassification values and corresponding suitability ratings for each criterion are provided in Table S2.

Table 2. Exclusion criteria and constraints.

\begin{tabular}{|c|c|c|c|c|c|c|c|c|c|}
\hline \multirow{2}{*}{ Code } & \multirow{2}{*}{$\begin{array}{l}\text { Data } \\
\text { Layer }\end{array}$} & \multicolumn{2}{|c|}{ Criteria } & \multirow{2}{*}{$\begin{array}{l}\text { Restriction } \\
\text { Factor }\end{array}$} & \multirow{2}{*}{ Category } & \multirow{2}{*}{ Format } & \multirow{2}{*}{ Source } & \multirow{2}{*}{ Description } & \multirow{2}{*}{ References } \\
\hline & & Solar PV & Wind & & & & & & \\
\hline $\begin{array}{l}\mathrm{C} 1_{\mathrm{S}} \\
\mathrm{C} 1_{\mathrm{W}}\end{array}$ & $\begin{array}{l}\text { Resource } \\
\text { potential }\end{array}$ & $\begin{array}{c}\mathrm{GHI}> \\
3.56 \mathrm{kWh} / \mathrm{m}^{2}\end{array}$ & $\begin{array}{l}\text { Wind speed } \\
<5.5 \mathrm{~m} / \mathrm{s} \\
\text { at } 50 \mathrm{~m}\end{array}$ & - & Technical & Raster & $\begin{array}{l}\text { SolarGIS, } \\
\text { Global Solar } \\
\text { Atlas, Global } \\
\text { Wind Atlas }\end{array}$ & $\begin{array}{l}\text { GHI: It is the total } \\
\text { amount of microwave } \\
\text { radiation absorbed by } \\
\text { a horizontal surface } \\
\text { on the ground. } \\
\text { Wind speed: Average } \\
\text { annual wind speed at } \\
50 \text { m above ground in } \\
\text { off-grid areas. }\end{array}$ & [112-115] \\
\hline $\mathrm{C} 2$ & Slope & $>5^{\circ}$ & $>15^{\circ}$ & Topography & Technical & Raster & $\begin{array}{l}\text { Earthdata, } \\
\text { NAMRIA }\end{array}$ & $\begin{array}{l}\text { It is the degree of } \\
\text { inclination of the } \\
\text { surface, usually in } \\
\text { degrees or in percent } \\
\text { generated from DEM. }\end{array}$ & {$[106,107,116]$} \\
\hline C3 & Aspect & South-facing & - & Topography & Technical & Raster & Earthdata & $\begin{array}{l}\text { The orientation of } \\
\text { a surface and is } \\
\text { considered as the } \\
\text { slope direction. }\end{array}$ & [106-108,117] \\
\hline $\mathrm{C} 4$ & $\begin{array}{c}\text { Electric } \\
\text { networks }\end{array}$ & $<100 \mathrm{~m}$ & $<100 \mathrm{~m}$ & Technology & Technological & Vector & PALECO & $\begin{array}{l}\text { Transmission and } \\
\text { distribution } \\
\text { power lines }\end{array}$ & [118-120] \\
\hline $\mathrm{C} 5$ & Roads & $<100 \mathrm{~m}$ & $<500 \mathrm{~m}$ & Infrastructure & $\begin{array}{l}\text { Socio- } \\
\text { economic }\end{array}$ & Vector & $\begin{array}{l}\text { OpenStreet } \\
\text { Map, Google } \\
\text { Satellite }\end{array}$ & $\begin{array}{l}\text { Proximity to roads, } \\
\text { highways, paved } \\
\text { paths, unpaved } \\
\text { paths, etc. }\end{array}$ & $\begin{array}{c}{[43,117-} \\
119,121,122]\end{array}$ \\
\hline C6 & $\begin{array}{l}\text { Built-up } \\
\text { areas }\end{array}$ & $<500 \mathrm{~m}$ & $<1000 \mathrm{~m}$ & Infrastructure & $\begin{array}{l}\text { Socio- } \\
\text { economic }\end{array}$ & Vector & $\begin{array}{l}\text { OpenStreet } \\
\text { Map, Google } \\
\text { Satellite }\end{array}$ & $\begin{array}{c}\text { Residential, parking } \\
\text { lots, commercial } \\
\text { buildings, parks, } \\
\text { gardens, etc. }\end{array}$ & {$[123,124]$} \\
\hline $\mathrm{C} 7$ & $\begin{array}{l}\text { Water } \\
\text { bodies }\end{array}$ & $<100 \mathrm{~m}$ & $<100 \mathrm{~m}$ & Hydrology & Environmental & Vector & $\begin{array}{l}\text { OpenStreet } \\
\text { Map, Google } \\
\text { Satellite }\end{array}$ & $\begin{array}{l}\text { Lakes, rivers, } \\
\text { reservoirs, etc. }\end{array}$ & {$[115,121,125]$} \\
\hline $\mathrm{C} 8$ & $\begin{array}{l}\text { Land use/ } \\
\text { land cover }\end{array}$ & Avoid & Avoid & $\begin{array}{l}\text { Land use, } \\
\text { Ecology }\end{array}$ & Environmental & Vector & PhilGIS & $\begin{array}{l}\text { Irrigated areas, forests, } \\
\text { agricultural lands, } \\
\text { mangrove areas, etc. }\end{array}$ & {$[123,126-128]$} \\
\hline
\end{tabular}

\section{b. Spatial Decision Support}

MCDM allows for the evaluation and prioritization of alternative decisions, particularly for evaluating siting alternatives $[35,128,129]$. The most commonly used method is the analytic hierarchy process (AHP), initially developed by Prof. Thomas L. Saaty in 1977 [45]. However, according to [130], a traditional AHP has several limitations, such as (1) dealing with an unbalanced judgmental scale; (2) being unable to deal with the ambiguity and uncertainty associated with one's judgment to a number; (3) imprecise ranking; and (4) subjective judgment, in which the decision maker's preference greatly influences AHP results [131]. With this, [132] introduced the concept of fuzzy sets by using linguistic variables rather than numerical values. The application of a hybrid AHP and TOPSIS can provide reliable geospatial analysis for RE resource site selection. This paper used the fuzzy AHP-TOPSIS model, where the Fuzzy AHP was utilized to find out the weights of the criteria, and TOPSIS was used to rank the possible siting locations for solar $\mathrm{PV}$ and wind farms.

\section{- Fuzzy AHP Method}

The steps of the fuzzy AHP method are summarized as follows [130,133,134]:

Step 1. Determine the goal, alternatives, and criteria. 
Step 2. Create a pairwise comparison matrix (PCM) using Equation (1), where $n$ is the number of criteria, $\mathrm{w}_{i}$ denotes the weight for the $i$ criterion, and $\mathrm{a}_{i j}$ is the ratio of the weight of $i$ and $j$ criteria.

$$
\mathrm{a}_{i j}=\frac{\mathrm{w}_{i}}{\mathrm{w}_{j}}
$$

where $i, j=1,2, \ldots, n$.

$$
\mathrm{A}=\mathrm{a}_{i j} \cdot \frac{1}{\mathrm{a}_{i j}^{\mathrm{T}}}\left[\begin{array}{cccc}
1 & \mathrm{a}_{12} & \cdots & \mathrm{a}_{1 \mathrm{n}} \\
\mathrm{a}_{21} & 1 & \cdots & \mathrm{a}_{2 \mathrm{n}} \\
\vdots & \vdots & \ddots & \vdots \\
\mathrm{a}_{\mathrm{n} 1} & \mathrm{a}_{\mathrm{n} 2} & \cdots & 1
\end{array}\right]
$$

Step 3. Convert Saaty's numerical scale into a triangular fuzzy number (TFN). The FAHP scale has three values, the lower limit (l), medium limit (m), and the upper limit (u). Table 3 shows the linguistic values and the TFNs.

Step 4. Calculate the geometric mean using Equation (3), where $\mathrm{l}_{i j}, \mathrm{~m}_{i j}, \mathrm{u}_{i j}$ are geometric means in the TFN scale, and $\mathrm{k}$ is the number of decision-makers. The TFN matrix is consistent if the value of $1 \leq \mathrm{m} \leq \mathrm{u}$.

$$
\begin{aligned}
\mathrm{l}_{i j} & =\left(\prod_{\mathrm{k}=1}^{\mathrm{K}} \mathrm{l}_{i j k}\right)^{\frac{1}{\mathrm{k}}}, \\
\mathrm{m}_{i j} & =\left(\prod_{\mathrm{k}=1}^{\mathrm{K}} \mathrm{m}_{i j k}\right)^{\frac{1}{\mathrm{k}}}, \\
\mathrm{u}_{i j} & =\left(\prod_{\mathrm{k}=1}^{\mathrm{K}} \mathrm{u}_{i j k}\right)^{\frac{1}{\mathrm{k}}}
\end{aligned}
$$

Step 5. When the AHP numerical scale has been converted to FAHP scale values, calculate the fuzzy synthesis value $\left(\mathrm{S}_{\mathrm{i}}\right)$ given by Equations (4)-(6):

$$
\begin{gathered}
\sum_{i=j}^{m} \mathrm{M}_{g i}^{j}=\left(\sum_{i=j}^{m} \mathrm{l}_{i}, \sum_{i=1}^{n} \mathrm{~m}_{i}, \sum_{i=j}^{m} \mathrm{u}_{i}\right) \\
\frac{1}{\left(\sum_{i=j}^{m} \sum_{i=1}^{n} \mathrm{M}_{g i}^{j}\right)}=\frac{1}{\sum_{i=1}^{n} \mathrm{u}_{i}}, \frac{1}{\sum_{i=1}^{n} \mathrm{~m}_{i}}, \frac{1}{\sum_{i=1}^{n} \mathrm{l}_{i}} \\
\mathrm{~S}_{\mathrm{i}}=\sum_{\mathrm{j}=1}^{\mathrm{m}} \mathrm{M}_{\mathrm{gi}}^{\mathrm{j}} * \frac{1}{\left(\sum_{\mathrm{i}=\mathrm{j}}^{\mathrm{m}} \sum_{\mathrm{i}=1}^{\mathrm{n}} \mathrm{M}_{\mathrm{gi}}^{\mathrm{j}}\right)}
\end{gathered}
$$

Step 6. The last step is to calculate the crisp weights. It can be obtained through a defuzzification process as defined by:

$$
\mathrm{W}_{j}=\frac{1+\mathrm{m}+\mathrm{u}}{3}
$$

Step 7. Calculate the eigenvector, maximum eigenvalue, Consistency Index (CI), and the consistency ratio (CR) using Equations (8)-(10), where $\lambda_{\max }$ is the eigenvalue of paired comparison matrix, and RI is for random index (Table 4).

$$
\begin{gathered}
\lambda_{\max }=\frac{\sum \text { Ratio }}{\mathrm{n}} \\
\mathrm{CI}=\frac{\lambda_{\max }-\mathrm{n}}{\mathrm{n}-1}
\end{gathered}
$$




$$
\mathrm{CR}=\frac{\mathrm{CI}}{\mathrm{RI}}
$$

Table 3. Linguistic values and triangular fuzzy numbers.

\begin{tabular}{cccc}
\hline Linguistic Values & AHP Scale & TFN Scale $\mathbf{( 1 ,} \mathbf{~ m , ~} \mathbf{u})$ & Reciprocal TFN \\
\hline Equal importance & 1 & $(1,1,1)$ & $(1,1,1)$ \\
Intermediate value & 2 & $(1,2,3)$ & $(1 / 3,1 / 2,1)$ \\
Moderate importance & 3 & $(2,3,4)$ & $(1 / 4,1 / 3,1 / 2)$ \\
Intermediate value & 4 & $(3,4,5)$ & $(1 / 5,1 / 4,1 / 3)$ \\
Strong importance & 5 & $(4,5,6)$ & $(1 / 6,1 / 5,1 / 4)$ \\
Intermediate value & 6 & $(5,6,7)$ & $(1 / 7,1 / 6,1 / 5)$ \\
Very strong importance & 7 & $(6,7,8)$ & $(1 / 8,1 / 7,1 / 6)$ \\
Intermediate value & 8 & $(7,8,9)$ & $(1 / 9,1 / 8,1 / 7)$ \\
Extreme importance & 9 & $(9,9,9)$ & $(1 / 9,1 / 9,1 / 9)$ \\
\hline
\end{tabular}

Table 4. Random consistency values $[45,50]$.

\begin{tabular}{ccccccccccc}
\hline $\mathbf{N}$ & $\mathbf{1}$ & $\mathbf{2}$ & $\mathbf{3}$ & $\mathbf{4}$ & $\mathbf{5}$ & $\mathbf{6}$ & $\mathbf{7}$ & $\mathbf{8}$ & $\mathbf{9}$ & $\mathbf{1 0}$ \\
\hline $\mathrm{RI}$ & 0 & 0 & 0.58 & 0.90 & 1.12 & 1.24 & 1.32 & 1.41 & 1.45 & 1.49 \\
\hline
\end{tabular}

\section{- $\quad$ TOPSIS Method}

After getting the relative weights from FAHP, the TOPSIS method will rank the number of alternatives based on the criteria. TOPSIS is one of the classical MCDM methods initially developed by [135]. It is based on the concept that a chosen alternative has the shortest distance from the positive ideal solution. The one with the farthest distance is the negative ideal solution [131]. The steps of the TOPSIS method [49,107,136,137] are as follows:

Step 1. Create a decision matrix (D) containing all the criteria, alternatives, and criteria weights.

Step 2. Calculate the normalized decision matrix $\left(X_{i j}\right)$ using the following equation:

$$
\mathrm{X}_{i j}=\frac{\mathrm{x}_{i j}}{\sqrt{\sum_{i=1}^{m} \mathrm{x}_{i j}^{2}}}, i=1,2, \ldots, m, j=1,2, \ldots, n
$$

Step 3. Calculate the weighted normalized decision matrix $\left(X_{i j}\right)$ by multiplying the normalized decision matrix $\left(\mathrm{X}_{i j}\right)$ by the weight $\left(\mathrm{w}_{j}\right)$ of the indicator that came from the fuzzy AHP.

$$
\mathrm{V}_{\mathrm{ij}}=\mathrm{X}_{\mathrm{ij}} * \mathrm{w}_{\mathrm{j}}
$$

Step 4. Determine the positive and negative ideal solution. The positive ideal solution $\left(\mathrm{A}^{+}\right)$is the maximum value of $\mathrm{V}_{\mathrm{ij}}$, and the negative ideal solution $\left(\mathrm{A}^{-}\right)$ is the minimum value.

$$
\begin{aligned}
& \mathrm{A}^{+}=\left[\mathrm{v}_{1}^{+}, \ldots, \mathrm{v}_{\mathrm{n}}^{+}\right], \mathrm{v}_{\mathrm{j}}^{+}=\max \left\{\mathrm{v}_{\mathrm{ij}}\right\} \\
& \mathrm{A}^{-}=\left[\mathrm{v}_{1}^{-}, \ldots, \mathrm{v}_{\mathrm{n}}^{-}\right], \mathrm{v}_{\mathrm{j}}^{-}=\min \left\{\mathrm{v}_{\mathrm{ij}}\right\}
\end{aligned}
$$

Step 5. Calculate the Euclidean distance of each alternative from positive and negative ideal solutions $\left(\mathrm{A}^{+}, \mathrm{A}^{-}\right)$.

$$
\begin{aligned}
& \mathrm{d}_{\mathrm{i}}^{+}=\sqrt{\sum_{\mathrm{j}=1}^{\mathrm{n}}\left(\mathrm{v}_{\mathrm{ij}}-\mathrm{v}_{\mathrm{j}}^{+}\right)^{2}} \\
& \mathrm{~d}_{\mathrm{i}}^{-}=\sqrt{\sum_{\mathrm{j}=1}^{\mathrm{n}}\left(\mathrm{v}_{\mathrm{ij}}-\mathrm{v}_{\mathrm{j}}^{-}\right)^{2}}
\end{aligned}
$$


Step 6. Calculate the performance score $(\mathrm{CP})$ of each alternative to the positive ideal solution $\left(\mathrm{A}^{+}\right)$.

$$
\mathrm{CP}_{\mathrm{i}}=\frac{\mathrm{d}_{\mathrm{i}}^{-}}{\left(\mathrm{d}_{\mathrm{i}}^{+}+\mathrm{d}_{\mathrm{i}}^{-}\right)}
$$

Step 7. Rank the alternatives according to the performance score, where the shortest distance is the positive ideal solution, and the farthest distance is the negative ideal solution.

\subsubsection{Technical Potential Estimation}

The goal of the technical potential estimation is to determine the generation capacity of each RE resource for energy access. Based on the calculated area from GIS and with the aid of HelioScope, the actual solar PV panels installation area can be simulated, and the annual electricity generation capacity will be obtained. This is then fed to HOMER Pro to determine whether the system is feasible or not. Viable power systems as well as battery storage size are obtained, and the monthly power generation is determined.

The forecasted demand from the first phase and the projected supply from renewable energy sources in this stage will be compared to determine if the full utilization of these resources can meet the energy demand, and as a result, support the global and national transition to cleaner energy sources.

\section{Results}

\subsection{Assessment Stage}

\subsubsection{Current Energy Profile of the Case Areas}

The island communities have residential dwellings, public buildings (municipal hall, essential health services facilities, churches, schools), and commercial establishments (resorts and transient houses, small restaurants, construction hardware, grocery, dry good stores). The Palawan Electric Cooperative (PALECO) manages and operates the islands' power supply, stand-alone diesel power plants, which are not connected to the primary grid of Palawan. Only the island of Cuyo has a $24 \mathrm{~h}$ supply of electricity. In Araceli, only 2 out of 13 barangays have a 24 h electricity supply and in Balabac, only 6 out of 20 barangays. Those who do not have continuous access use generators from the local village for $4-5 \mathrm{~h}$ daily. The electric load profile from 2017 to 2021 was obtained from NPC and is shown in Table 5.

Table 5. Annual electric load demand of the study areas.

\begin{tabular}{cccc}
\hline \multirow{2}{*}{ Year } & \multicolumn{3}{c}{ Energy Demand (MWh) } \\
\cline { 2 - 4 } & Araceli & Balabac & Cuyo \\
\hline 2017 & 790.850 & 499.404 & 5855.638 \\
2018 & 949.633 & 552.387 & 6337.064 \\
2019 & 1054.212 & 705.619 & 6848.156 \\
2020 & 1186.260 & 843.871 & 7406.970 \\
2021 & 1242.335 & 931.602 & 7407.427 \\
\hline
\end{tabular}

\subsubsection{Load Forecasting}

The energy load demand was predicted until 2030 (see Table S3). It was summed up to obtain the yearly projected load demand, as presented in Table 6, followed by the smoothing trend line of the Holt-Winters method plot as shown in Figure 5 with confidence intervals of $80 \%$ and $95 \%$. The predicted energy demand in Araceli for the year 2030 is $1612.724 \mathrm{MWh}$, an increase of 30\% from the 2021 data. In Balabac, there is a $131 \%$ of forecasted demand from 931.602 to 2147.121 MWh. The current energy demand of 7407.427 MWh in Cuyo is expected to increase by $75 \%$ by 2030, which gives a predicted load demand of $12,958.001$. With confidence intervals of $80 \%$ and $95 \%$, it is expected that the expected value may fall on those intervals. 
Table 6. Forecasted energy demand.

\begin{tabular}{cccc}
\hline \multirow{2}{*}{ Year } & \multicolumn{3}{c}{ Energy Demand (MWh) } \\
\cline { 2 - 4 } & Araceli & Balabac & Cuyo \\
\hline 2022 & 1285.385 & 1075.364 & 8065.971 \\
2023 & 1326.303 & 1209.334 & 8677.474 \\
2024 & 1367.220 & 1343.303 & 9288.978 \\
2025 & 1408.137 & 1477.273 & 9900.482 \\
2026 & 1449.055 & 1611.242 & $10,511.986$ \\
2027 & 1489.972 & 1745.212 & $11,123.489$ \\
2028 & 1530.889 & 1879.182 & $11,734.993$ \\
2029 & 1571.807 & 2013.151 & $12,346.497$ \\
2030 & 1612.724 & 2147.121 & $12,958.001$ \\
\hline
\end{tabular}

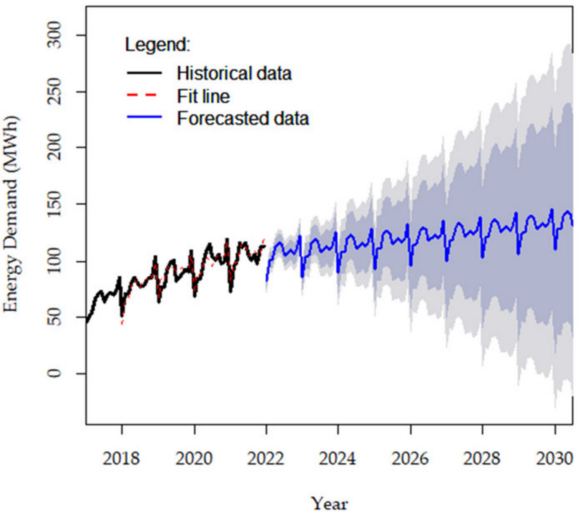

(a)

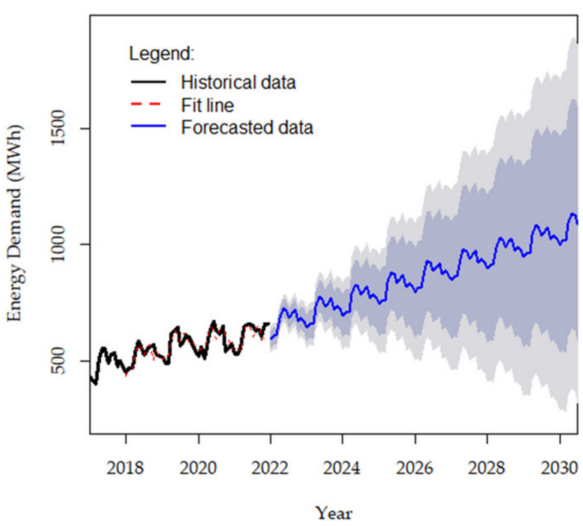

(c)

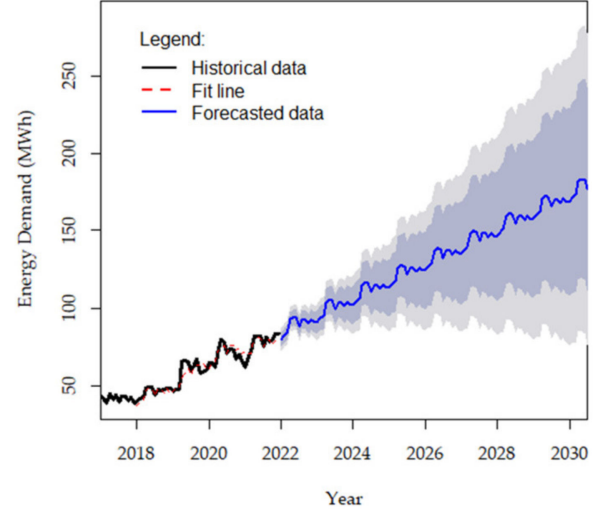

(b)

Figure 5. Holt-Winters method plot for (a) Araceli, (b) Balabac, and (c) Cuyo.

\subsection{Geospatial Analysis}

The study areas were defined using GIS data for the region of Palawan, the Philippines. The boundaries of the three off-grid island communities (Araceli, Balabac, and Cuyo Islands) were extracted for use as a mask for all criteria. The data were uploaded to QGIS, including base criteria such as DEM, solar radiation, wind speed, aspect, and slope. Then, the application of the qualifiers layer was implemented to assess the land quality of the areas being investigated. The preparation of the maps before the exclusion criteria and constraints were implemented is presented in Figure S1.

\section{a. Spatial Analysis}

GHI in the country has an annual potential average of $5.1 \mathrm{kWh} / \mathrm{m}^{2} /$ day [138]. For the three study areas, the GHI values are as follows: Araceli has a GHI of $5.26 \mathrm{kWh} / \mathrm{m}^{2} /$ day, 
Balabac has a GHI of $4.98 \mathrm{kWh} / \mathrm{m}^{2} /$ day, and Cuyo has a GHI of $5.35 \mathrm{kWh} / \mathrm{m}^{2} /$ day [139]. The slopes are extracted from DEM in the QGIS slope tool, and a slope of more than $5^{\circ}$ was excluded because it affects the reception of solar radiation. The aspect was also extracted from DEM using the aspect tool in QGIS.

The solar and wind farm locations should be near electric networks and road infrastructures to avoid transmission losses and high economic costs $[30,140]$. The Euclidian distance was utilized to calculate the nearest source based on straight-line distance. Proximity to built-up areas and water bodies were also reclassified using the raster calculator in QGIS.

After applying all of the exclusion criteria and constraints set in Table 2, the result of the spatial analysis is shown in Figure S4.

b. Spatial Decision Support

Fuzzy AHP-TOPSIS was applied to eliminate infeasible areas to map suitable solar PV plant and wind farm locations. A hierarchical structure (Figure 6) was made to show how the criteria are used for evaluation to reach the common goal.

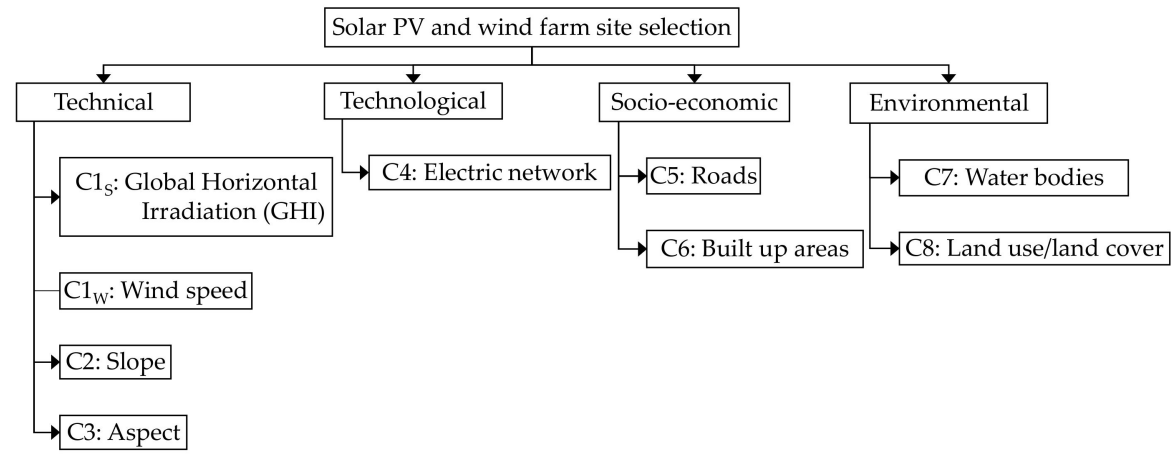

Figure 6. Hierarchical structure for Solar PV and wind farm site selection.

There are eight criteria for solar PV and seven for wind farm mapping. Therefore, the sizes of PCM are 64 (solar PV) and 49 (wind). The comparison matrix of the criteria using a numerical scale was converted into TFNs. The fuzzy weights were obtained using Equations (3)-(6), and through the defuzzification process, the crisp weight was calculated. Then, each crisp weight was divided by the sum of all crisp weights to obtain the normalized matrix. The maximum eigenvalue and Consistency Index (CI) for solar PV were calculated as 8.602 and 0.086 , respectively, and 7.428 and 0.071 for wind energy. With that, the CR values for the two RETs are 0.061 and 0.054 . Since all the values of CR for both solar PV and wind are less than 0.10, the value judgments are considered acceptable [140]. Table 7 shows the summary of the results for the Fuzzy AHP method.

In QGIS, the final normalized weights were used to identify the degree of importance of each criterion and the rasters of the exclusion criteria and constraints were used as input layers. The final rasters of the suitability map (SM) for solar PV farms (5) and wind farms (6) were calculated using the following expressions:

$$
\begin{aligned}
\mathrm{SM}_{\mathrm{S}}=0.316 \mathrm{C} 1 \mathrm{~S}+0.203 \mathrm{C} 2+0.189 \mathrm{C} 3+0.098 \mathrm{C} 4+0.071 \mathrm{C} 5+0.055 \mathrm{C} 6+0.033 \mathrm{C} 7+0.044 \mathrm{C} 8 \\
\mathrm{SM}_{\mathrm{W}}=0.327 \mathrm{C} 1+0.267 \mathrm{C} 2+0.121 \mathrm{C} 4+0.105 \mathrm{C} 5+0.089 \mathrm{C} 6+0.045 \mathrm{C} 7+0.046 \mathrm{C} 8
\end{aligned}
$$

The final suitability map (Figures 7 and 8 ) is represented by binary values 0 and 1. "0" represents those areas that are not suitable, and " 1 " shows the best possible location for installing solar PV and wind power farms. 
Table 7. Comparison matrix sum, final criteria weights, weighted sum value, and ratio.

\begin{tabular}{|c|c|c|c|c|c|c|c|}
\hline \multirow{2}{*}{ Criteria } & \multirow{2}{*}{ Sub-Criteria } & \multicolumn{2}{|c|}{ FUZZY Weight } & \multicolumn{2}{|c|}{ Crisp Weight } & \multicolumn{2}{|c|}{ Normalized Weight } \\
\hline & & Solar PV & Wind & Solar PV & Wind & Solar PV & Wind \\
\hline \multirow[t]{4}{*}{ Technical } & C1s GHI & $(0.201,0.319,0.490)$ & - & 0.337 & - & 0.316 & - \\
\hline & C1w Wind speed & - & $(0.192,0.333,0.540)$ & - & 0.355 & - & 0.327 \\
\hline & C2 Slope & $(0.135,0.204,0.309)$ & $(0.154,0.265,0.453)$ & 0.216 & 0.291 & 0.203 & 0.267 \\
\hline & C3 Aspect & $(0.124,0.190,0.291)$ & - & 0.202 & - & 0.189 & - \\
\hline Technological & C4 Electric network & $(0.064,0.097,0.153)$ & $(0.082,0.122,0.189)$ & 0.105 & 0.131 & 0.098 & 0.121 \\
\hline \multirow[t]{2}{*}{ Socio-economic } & C5 Roads & $(0.046,0.071,0.111)$ & $(0.064,0.104,0.173)$ & 0.076 & 0.114 & 0.071 & 0.105 \\
\hline & C6 Built up areas & $(0.035,0.055,0.086)$ & $(0.058,0.092,0.142)$ & 0.059 & 0.097 & 0.055 & 0.089 \\
\hline \multirow{3}{*}{ Environmetal } & C7 Water bodies & $(0.021,0.033,0.053)$ & $(0.027,0.042,0.079)$ & 0.035 & 0.049 & 0.033 & 0.045 \\
\hline & C8 Land use/land cover & $(0.020,0.031,0.058)$ & $(0.025,0.042,0.082)$ & 0.036 & 0.050 & 0.034 & 0.046 \\
\hline & & & & & & $C R=0.061$ & $\mathrm{CR}=0.054$ \\
\hline
\end{tabular}

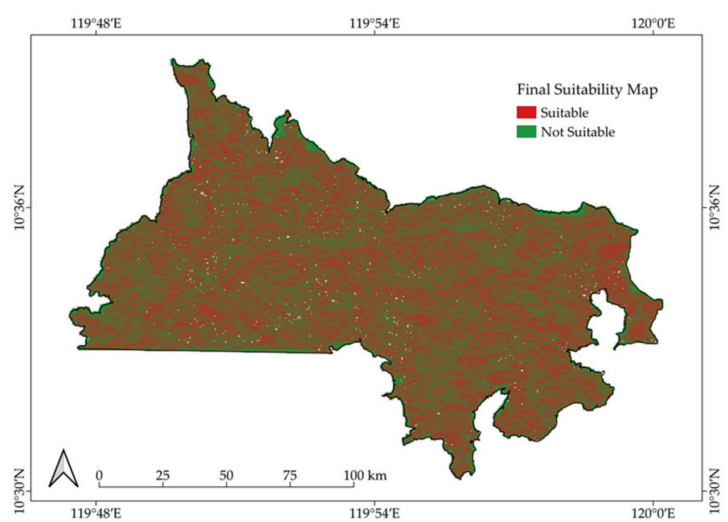

(a)

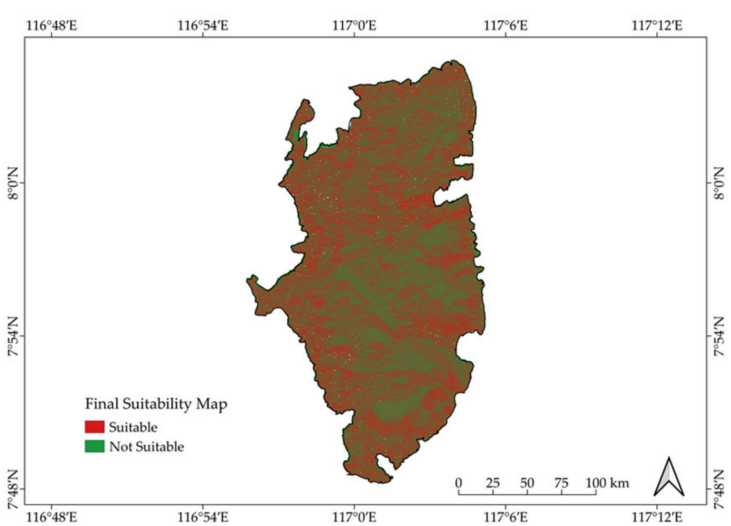

(b)

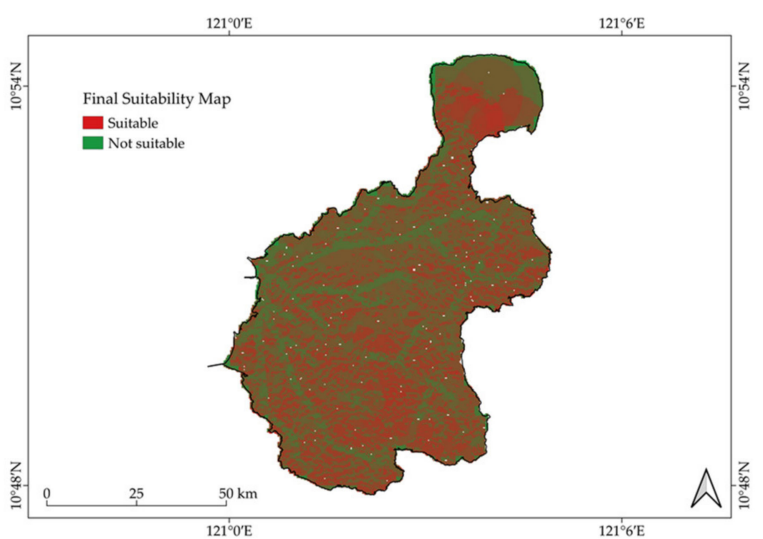

(c)

Figure 7. Final suitability map of solar PV: (a) Araceli; (b) Balabac; and (c) Cuyo.

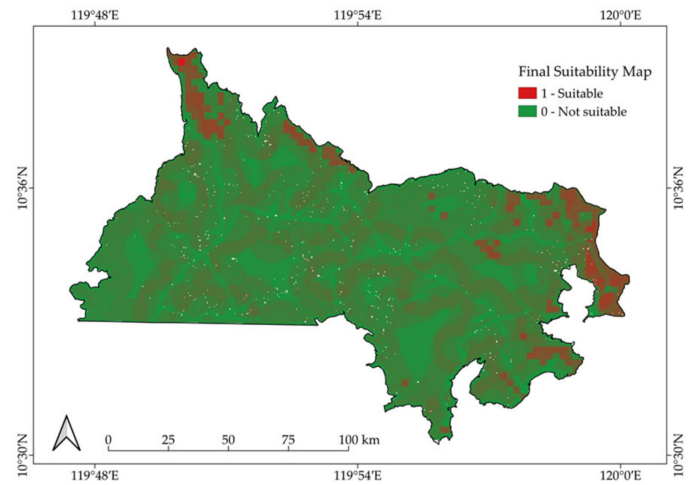

(a)

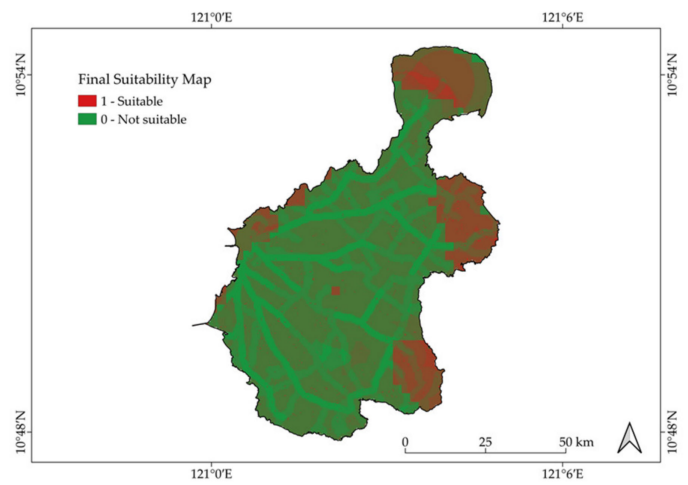

(b)

Figure 8. Final suitability map of wind energy: (a) Araceli; and (b) Cuyo. 
To produce $1 \mathrm{MWp}, 1-2$ hectares $\left(10,000-20,000 \mathrm{~m}^{2}\right)$ of land is needed for a solar farm, and 10 hectares $\left(100,000 \mathrm{~m}^{2}\right)$ of land is required to install a $1 \mathrm{MW}$ wind farm [141,142]. Areas below 5 hectares $\left(50,000 \mathrm{~m}^{2}\right)$ were excluded from the site selection for solar PV farms, and 10 hectares $\left(100,000 \mathrm{~m}^{2}\right)$ for wind farms, and those near agricultural farms. Additionally, since this study considered island communities, $500 \mathrm{~m}$ from the seashore was considered a buffer zone. Since Cuyo has an airport, a $5000 \mathrm{~m}$ buffer zone from the airport was also considered. Then, a visual inspection by georeferencing on Google Earth was performed to obtain the best results of potential sites.

The application of the TOPSIS method ranked the locations based on the given criteria. The weighted normalized decision matrix was calculated using Equation (12) by multiplying the normalized decision matrix by the indicator's weight from the fuzzy AHP analysis. The Euclidean distance of each alternative from the positive and negative ideal solutions was obtained, and the performance score was calculated. Table 8 presents the summary of the TOPSIS method showing the number of possible locations and the total calculated area in square kilometers and the ranking of feasible selection sites. Figures 9 and 10 show where these possible locations are situated.

The areas stated are for solar PV and wind farm suitability mapping. The ownership of the land and other governmental concerns were not considered.

\subsection{Technical Potential Estimation}

The three islands currently use diesel generators with an installed rated capacity of 1.386, 1.086, and 3.2 MW. Based on the ranked locations from Table 8, the first-ranked locations are chosen as the most feasible locations. These were then simulated in HelioScope to determine the generated potential rated capacity and solar PV's estimated annual generation potential. Simulation results in HelioScope were used in HOMER Pro to determine the system's feasibility. The most viable power system was obtained with different technology options and resource availability. Table 9 shows each renewable resource's demand and production profile and the energy storage needed to replace the existing diesel generator sets, while Figures 11-13 display the time series plots on an hourly basis of the demand, production, and unmet electrical loads of solar PV and wind.

Table 8. Calculated area and performance scores of possible locations.

\begin{tabular}{|c|c|c|c|c|c|c|c|c|c|c|}
\hline \multirow{3}{*}{$\begin{array}{l}\text { Study Area } \\
\text { and Locations }\end{array}$} & \multicolumn{2}{|c|}{ Total Area $\left(\mathrm{m}^{2}\right)$} & \multicolumn{8}{|c|}{ Performance Score } \\
\hline & \multirow{2}{*}{ Solar PV } & \multirow{2}{*}{ Wind } & \multicolumn{4}{|c|}{ Solar PV } & \multicolumn{4}{|c|}{ Wind } \\
\hline & & & $d_{i}^{+}$ & $d_{i}^{-}$ & $C P_{i}$ & Rank & $d_{i}^{+}$ & $d_{i}^{-}$ & $C P_{i}$ & Rank \\
\hline \multicolumn{11}{|c|}{ Araceli } \\
\hline L1 & 131,813 & $4,563,000$ & 0.048 & 0.088 & 0.646 & $3 \mathrm{rd}$ & 0.110 & 0.133 & 0.546 & $1 s t$ \\
\hline L2 & 182,860 & 8178,000 & 0.088 & 0.059 & 0.404 & 5 th & 0.133 & 0.110 & 0.454 & 2nd \\
\hline L3 & 181,688 & - & 0.047 & 0.087 & 0.649 & 2nd & - & - & - & - \\
\hline $\mathrm{L} 4$ & 51,585 & - & 0.060 & 0.086 & 0.590 & 4th & - & - & - & - \\
\hline L5 & 238,280 & - & 0.008 & 0.101 & 0.922 & 1 st & - & - & - & - \\
\hline \multicolumn{11}{|c|}{ Balabac } \\
\hline L1 & 226,891 & - & 0.054 & 0.058 & 0.514 & $3 \mathrm{rd}$ & - & - & - & - \\
\hline L2 & 238,558 & - & 0.025 & 0.065 & 0.723 & 1 st & - & - & - & - \\
\hline L3 & 121,919 & - & 0.060 & 0.037 & 0.381 & 4 th & - & - & - & - \\
\hline $\mathrm{L} 4$ & 133,057 & - & 0.043 & 0.055 & 0.563 & 2 nd & - & - & - & - \\
\hline \multicolumn{11}{|c|}{ Cuyo } \\
\hline L1 & 200,565 & $4,330,000$ & 0.020 & 0.025 & 0.550 & 2nd & $* *$ & $* *$ & $* *$ & $1 \mathrm{st}$ \\
\hline L2 & 54,498 & - & 0.036 & 0.004 & 0.092 & $3 \mathrm{rd}$ & - & - & - & - \\
\hline L3 & 225,405 & - & 0.005 & 0.035 & 0.881 & 1 st & - & - & - & - \\
\hline
\end{tabular}

** Ranking is not applicable since it has only one alternative. 


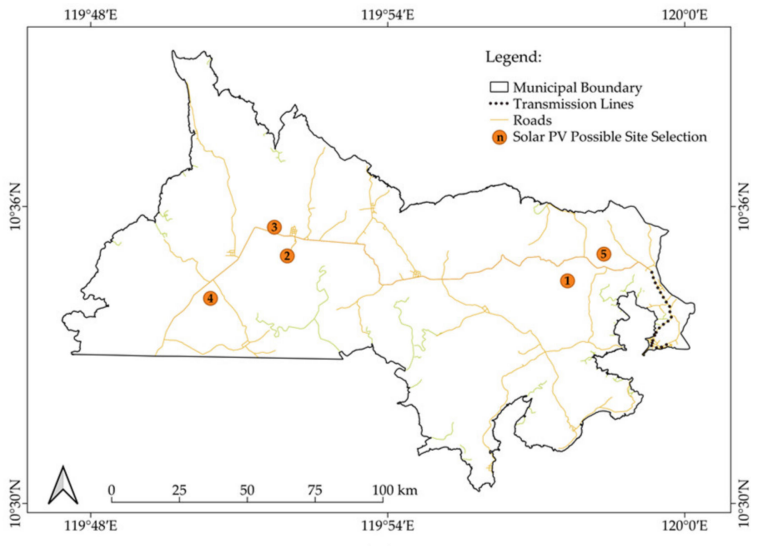

(a)

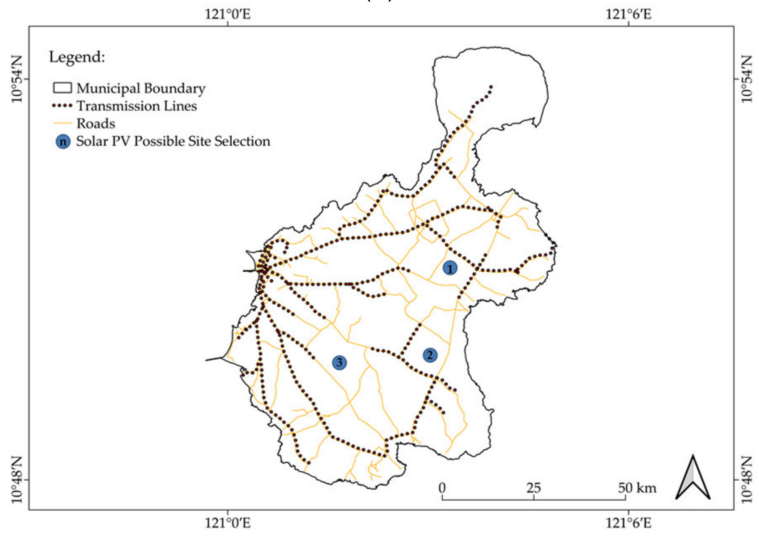

(c)

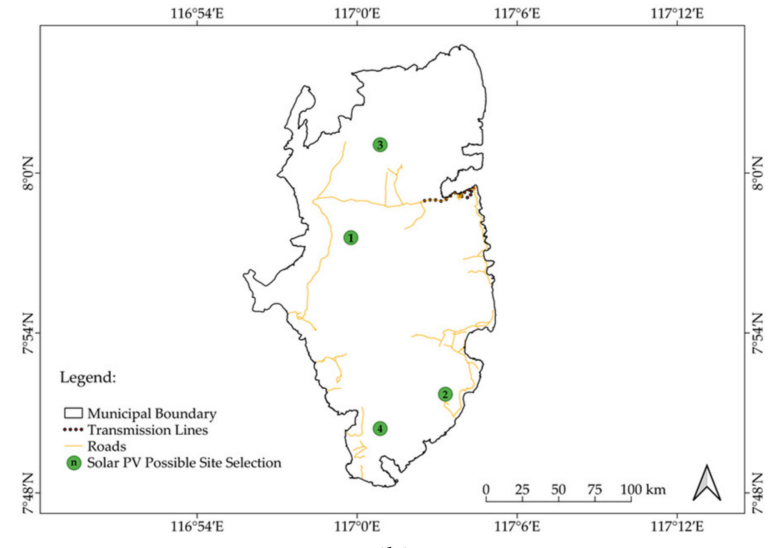

(b)

Figure 9. Possible locations for solar PV farms: (a) Araceli; (b) Balabac; and (c) Cuyo.

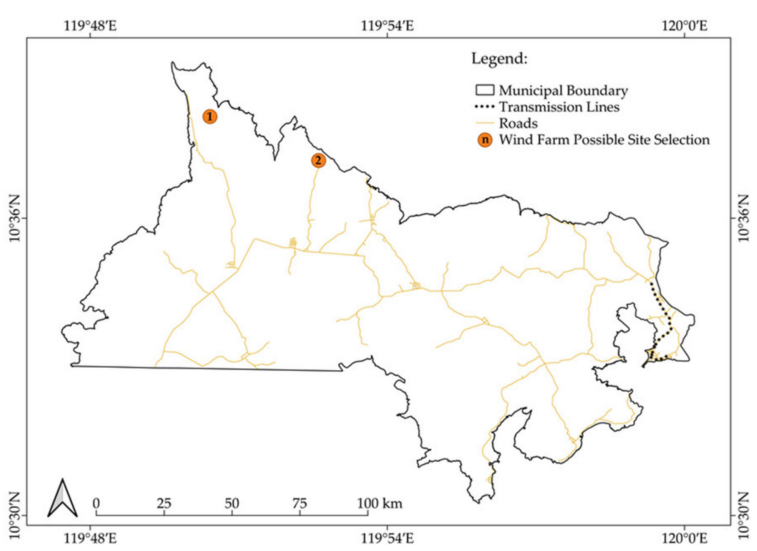

(a)

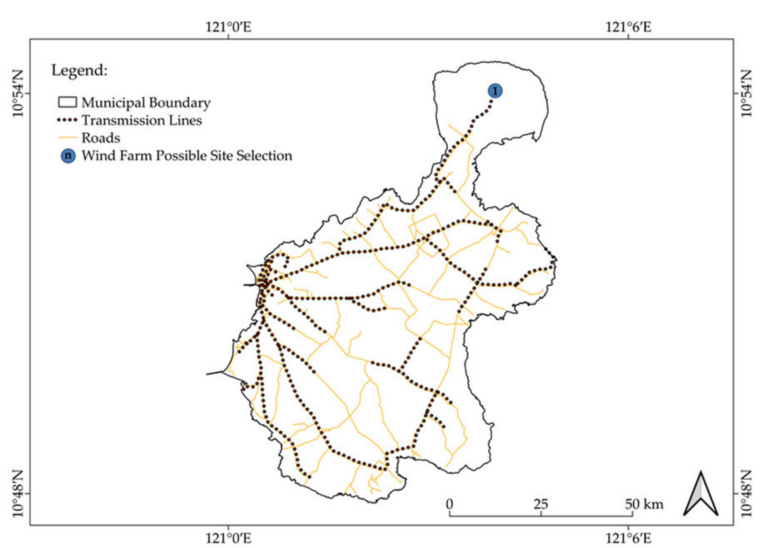

(b)

Figure 10. Possible locations for solar PV farms: (a) Araceli; and (b) Cuyo. 
Table 9. Electricity generation capacity and annual generation potential of solar PV and wind.

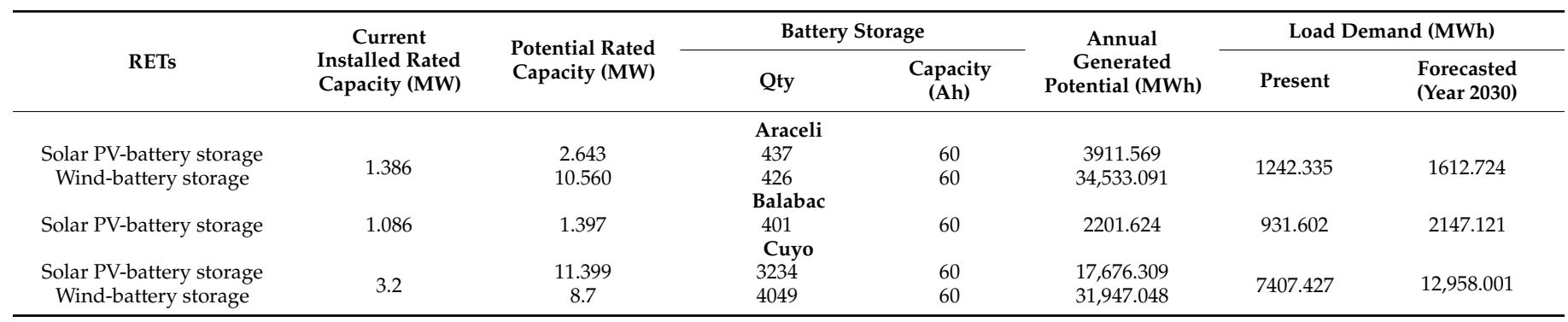

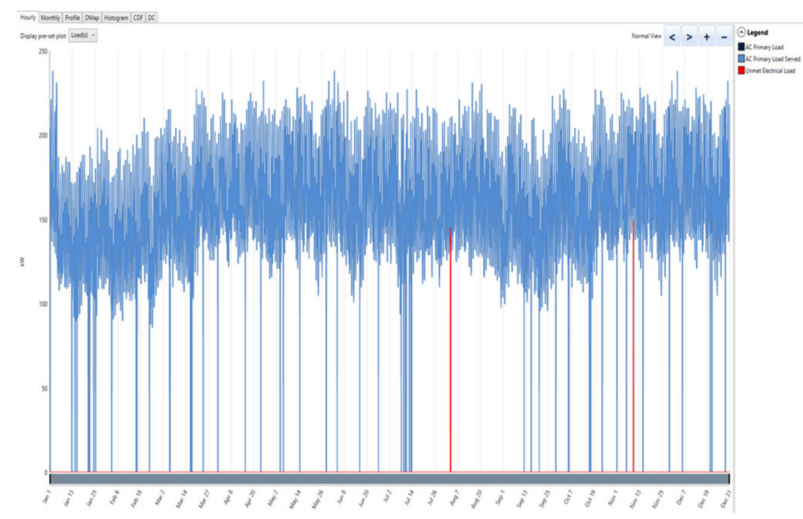

(a)

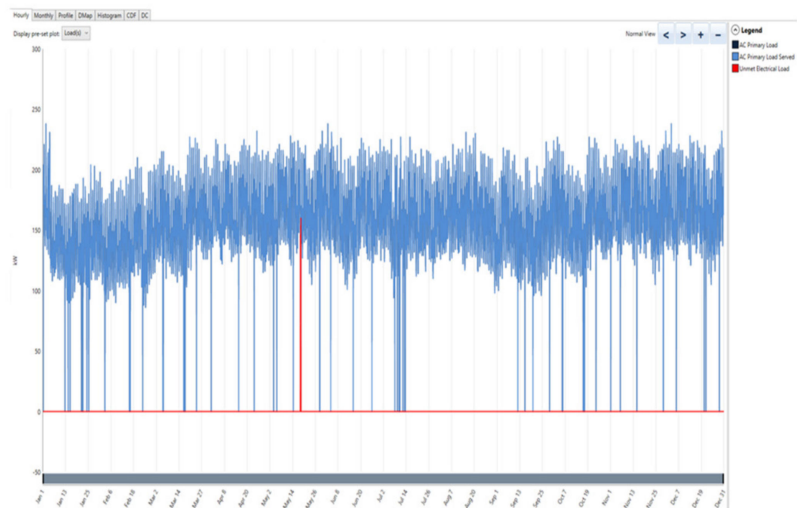

(b)

Figure 11. Demand, production, and unmet electrical loads in Araceli: (a) solar PV and (b) wind.

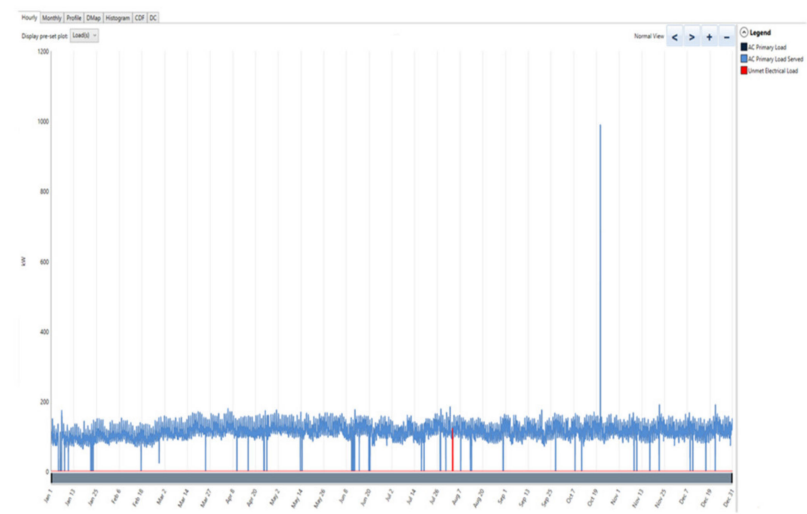

Figure 12. Demand, production, and unmet electrical loads of solar PV in Balabac.

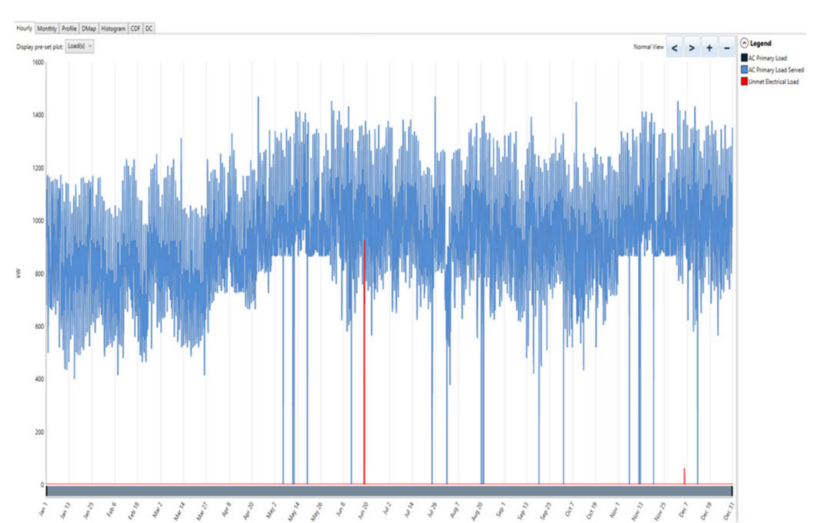

(a)

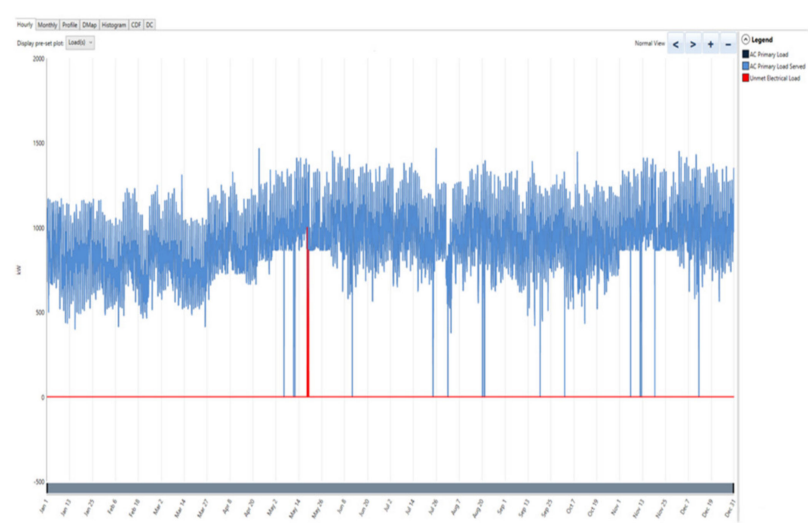

(b)

Figure 13. Demand, production, and unmet electrical loads in Cuyo: (a) solar PV and (b) wind. 
The best locations for solar PV installations in Araceli, Balabac, and Cuyo have a potential rated capacity of 2.643,1.397, and $11.399 \mathrm{MW}$, respectively, and an estimated annual potential generation of 3.912, 2.202, and 17.676 GWh, respectively. For wind renewable technology, Araceli's and Cuyo's best locations for wind turbine installation have an estimated rated capacity of 10.56 and $8.7 \mathrm{MW}$, respectively with estimated annual potential generation of 34.533 and $31.947 \mathrm{GWh}$. For all three islands, the solar potential alone can already satisfy the forecasted load demand up to 2030, and it can replace the existing conventional diesel generator sets. However, due to the intermittent characteristics of solar energy, wind power should be installed to back up the energy supply.

\section{Discussions and Conclusions}

This paper aimed to determine if renewable energy sources available in off-grid island communities are enough to meet the electricity demand at the household, commercial, and institutional levels. In order to do this, a three-phased approach was used: an assessment stage, geospatial analysis, and technical potential estimation. In the assessment stage, the site and load profile analysis was performed to analyze the present energy status of the research areas. Load forecasting was also included to anticipate the demand for electricity until 2030. The Holt-Winters exponential smoothing method in the R package was utilized to forecast the future load using the historical data. The predicted energy demand in Araceli is 1612.724 MWh, 2147.121 MWh in Balabac, and 12,958.001 MWh in Cuyo, with an increase of $30 \%, 131 \%$, and $75 \%$, respectively, from the current load demand.

The second approach is the geospatial analysis, during which the open-source software QGIS and, among the decision-making techniques, the MCDM Fuzzy AHP-TOPSIS method were used. The aim was to identify the exclusion factors and constraints affecting the choice of suitable locations for installing renewable energy technologies. The potential locations for solar PV and wind energy resources available in the study areas were identified and mapped, and the number of possible sites was determined. There are 12 potential sites for solar PV farms and 3 locations for wind farms among the three study areas. Each location was ranked based on the considerations that it is near the electric networks, roads, and built-up areas but far from water bodies and protected areas.

The technical potential estimation is the last approach used in this study. It aims to determine the available generated capacity of RE resources. Based on the calculation, the annual generation potential was estimated based on the calculated area of each feasible site obtained from the resource mapping. The generation capacity for each RE technology that can be installed in all study sites are as follows: Araceli needs a generation capacity of $3 \mathrm{MW}$ (solar) and $10 \mathrm{MW}$ (wind); Balabac may consider installing a generation capacity of 1.5 MW (solar); and a generation capacity of $11 \mathrm{MW}$ (solar) and $9 \mathrm{MW}$ (wind) is required by Cuyo. If solar PV farms are installed with their generation capacity as stated, they can replace the existing diesel power plant. The expected power generation potential is more than enough to supply the projected demand until 2030. However, there are some areas that the electric network has not yet reached; thus, if there is for a hundred percent energy access, a capacity addition is required.

In conclusion, resource mapping of renewable energy sources using GIS in these communities is of great importance, particularly to those off-grid islands that are not connected to the primary grid. However, in energy planning, it must be done in conjunction with determining whether such available resources can sufficiently supply for the demand of the islands. Furthermore, selecting the appropriate locations of RET implementations must be done. In this paper, the fuzzy AHP-TOPSIS approach was used to rank the alternatives based on set criteria. The estimations of the generation potential helped to obtain the required capacity of each RET to replace the existing diesel power plants in Araceli, Balabac, and Cuyo. The forecasting method applied has contributed significantly to predicting future demand, thus achieving the goal of this study. Therefore, the methodology used contributes to the literature, which can be used in similar studies of RE resource mapping. As a concluding remark, the neglected off-grid areas are the best place to start 
in the transition to cleaner energy sources while achieving the goal of universal access to electricity.

Future works include other RE resources, i.e., biomass, geothermal, offshore wind, and hydro, in mapping resources potential. Additionally, it is recommended to consider the economic potential and technical system design, including protection, coordination, and systematic load dispatching if renewables are to be fully utilized in off-grid areas' transition to cleaner energy.

Supplementary Materials: The following are available online at https:/ /www.mdpi.com/article/10 .3390/app112411955/s1, Table S1: Summary of research studies on energy planning using GIS; Table S2: Reclassification values of exclusion criteria and constraints; Table S3: Result of Holt-Winters Exponential Smoothing Method for Balabac. Figure S1: GIS maps before the application of exclusion criteria and constraints. Araceli: (a) DEM; (b) GHI; (c) wind speed; (d) slope; (e) aspect; (f) electric network; (g) roads; (h) built-ups; (i) water bodies; (j) land use/land cover; Figure S2: Balabac: (a) DEM; (b) GHI; (c) slope; (d) aspect; (e) electric network; (f) roads; (g) built-ups; (h) water bodies; (i) land use/land cover. (j) water bodies; (k) land use/land cover; Figure S3: Cuyo: (a) DEM; (b) GHI; (c) wind speed; (d) slope; (e) aspect; (f) electric network; (g) roads; (h) built-ups; (i) water bodies; (j) land use/land cover; Figure S4: GIS reclassification maps, Reclassification of datasets in Araceli: (a) GHI; (b) wind speed; (c) slope; (d) aspect; (e) electric network; (f) roads; (g) builtups; (h) water bodies; and (i) land use/land cover; Figure S5: Reclassification of datasets in Balabac: (a) GHI; (b) slope; (c) aspect; (d) electric network; (e) roads; (f) built ups; (g) water bodies, and (h) land use/land cover; Figure S6: Reclassification of datasets in Cuyo: (a) GHI; (b) wind speed; (c) slope; (d) aspect; (e) electric network; (f) roads; (g) builtups; (h) water bodies; and (i) land use/land cover.

Author Contributions: Conceptualization, K.R.M.S., L.L., I.D.F.T. and E.M.Q.; methodology, K.R.M.S. and L.L.; software, K.R.M.S.; validation, K.R.M.S. and L.L.; formal analysis, K.R.M.S.; investigation, K.R.M.S.; resources, K.R.M.S.; data curation, K.R.M.S.; writing—original draft preparation, K.R.M.S.; writing-review and editing, L.L., I.D.F.T. and E.M.Q.; visualization, K.R.M.S.; supervision, L.L., I.D.F.T. and E.M.Q.; project administration, L.L., I.D.F.T. and E.M.Q.; funding acquisition, E.M.Q. All authors have read and agreed to the published version of the manuscript.

Funding: This research received no external funding from funding agencies in the public, commercial, or not-for-profit sectors.

Institutional Review Board Statement: The study was conducted with the approval of the University of San Carlos Research Ethics Committee (Protocol Number 084/2019-11-supapo and the Approval Date 12 December 2019).

Informed Consent Statement: Informed consent was obtained from all subjects involved in the study.

Data Availability Statement: Data are available upon request.

Acknowledgments: The authors would like to extend their sincerest gratitude to the following: the Department of Science and Technology-Engineering Research and Development for Technology (DOST-ERDT) for providing financial support; to the University of San Carlos (USC) School of Engineering for giving the chance of having a professional advancement; to the local government units and residents of the municipalities of Araceli, Balabac, and Cuyo for allowing us to carry out the research surveys.

Conflicts of Interest: The authors declare that they have no known competing financial interests or personal relationships that could have appeared to influence the work reported in this paper. 


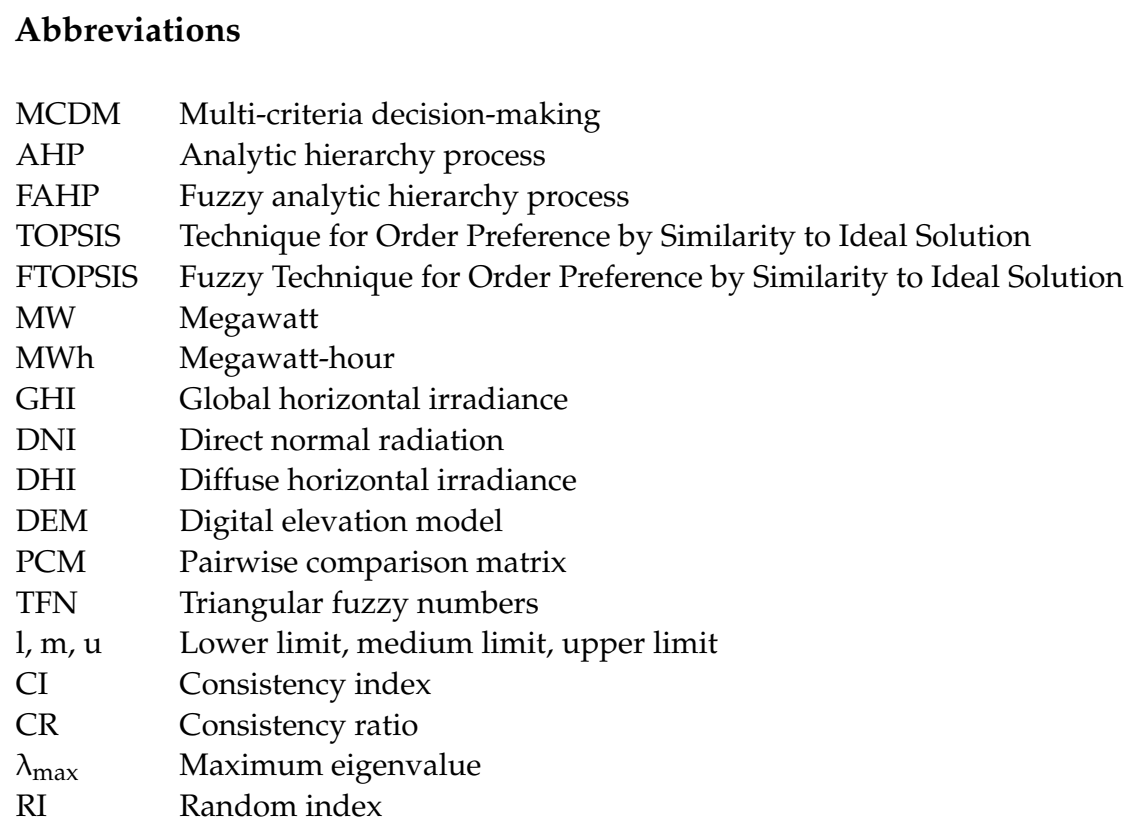

\section{References}

1. BP. Statistical Review of World Energy: 70th Edition. Available online: https://www.bp.com/content/dam/bp/business-sites/en/ global/corporate/pdfs/energy-economics/statistical-review/bp-stats-review-2021-full-report.pdf (accessed on 15 October 2021).

2. Nunez, C. What Are Fossil Fuels? Available online: https://www.nationalgeographic.com/environment/energy/reference/ fossil-fuels/ (accessed on 5 January 2020).

3. United Nations. Sustainable Development Goals. Available online: https://www.un.org/sustainabledevelopment/climateaction/ (accessed on 5 January 2020).

4. International Energy Agency. Global Energy and $\mathrm{CO}_{2}$ Status Report 2018. Available online: https://webstore.iea.org/global-energyco2-status-report-2018 (accessed on 10 September 2019).

5. International Energy Agency. Global Energy Review 2020: The Impacts of the COVID-19 Crisis on Global Energy Demand and $\mathrm{CO}_{2}$ Emissions. Available online: https:/ / webstore.iea.org/download/direct/2995 (accessed on 3 February 2021).

6. Department of Energy. Energy Annual Report 2017. Available online: https://www.doe.gov.ph/sites/default/files/pdf/ transparency/annual_report_esar_2017.pdf (accessed on 6 May 2020).

7. Asian Development Bank. Philippines Energy Sector Assessment, Strategy, and Road Map. Available online: https://www.adb.org/ sites/default/files/publication/463306/philippines-energy-assessment-strategy-road-map.pdf (accessed on 8 September 2019).

8. The World Bank. SE4ALL Global Tracking Framework. Available online: https://data.worldbank.org/indicator/EG.ELC.ACCS ZS?locations=PH (accessed on 5 February 2021).

9. International Renewable Energy Agency. Renewable Readiness Assessment: The Philippines. Available online: https://www. irena.org/DocumentDownloads/Publications/IRENA_RRA_Philippines_2017.pdf (accessed on 22 September 2019).

10. Amjad, F.; Shah, L.A. Identification and assessment of sites for solar farms development using GIS and density based clustering technique- A case of Pakistan. Renew. Energy 2020, 155, 761-769. [CrossRef]

11. Pillot, B.; Al-Kurdi, N.; Gervet, C.; Linguet, L. An integrated GIS and robust optimization framework for solar PV plant planning scenarios at utility scale. Appl. Energy 2020, 260, 114257. [CrossRef]

12. Jeong, J.S.; Ramírez-Gómez, Á. Renewable energy management to identify suitable biomass facility location with GIS-based assessment for sustainable environment. Energy Procedia 2017, 136, 139-144. [CrossRef]

13. Saha, M.; Eckelman, M.J. Geospatial assessment of regional scale bioenergy production potential on marginal and degraded land. Resour. Conserv. Recycl. 2018, 128, 90-97. [CrossRef]

14. Castro-Santos, L.; Garcia, G.P.; Simões, T.; Estanqueiro, A. Planning of the installation of offshore renewable energies: A GIS approach of the Portuguese roadmap. Renew. Energy 2019, 132, 1251-1262. [CrossRef]

15. Díaz, H.; Soares, C.G. An integrated GIS approach for site selection of floating offshore wind farms in the Atlantic continental European coastline. Renew. Sustain. Energy Rev. 2020, 134, 110328. [CrossRef]

16. Zheng, Y.; Weng, Q. Modeling the effect of climate change on building energy demand in Los Angeles county by using a GIS-based high spatial- and temporal-resolution approach. Energy 2019, 176, 641-655. [CrossRef]

17. Usman, A.; Shamsi, M.H.; Bohacek, M.; Purcell, K.; Hoare, C.; Mangina, E.; O’Donnell, J. A data-driven approach for multi-scale GIS-based building energy modeling for analysis, planning and support decision making. Appl. Energy 2020, 279, 115834. [CrossRef]

18. United Nations Development Programme. Sustainable Development Goals. Available online: https://www.undp.org/content/ undp/en/home/sustainable-development-goals/goal-7-affordable-and-clean-energy.html (accessed on 19 December 2019). 
19. REN 21. Renewables 2020 Global Status Report. Available online: https://www.ren21.net/wp-content/uploads/2019/05/gsr_ 2020_full_report_en.pdf (accessed on 3 February 2021).

20. Ayamolowo, O.J.; Manditereza, P.T.; Kusakana, K. Exploring the Gaps in Renewable Energy Integration to Grid. Energy Rep. 2020, 6, 992-999. [CrossRef]

21. Alberizzi, J.C.; Frigola, J.M.; Rossi, M.; Renzi, M. Optimal sizing of a Hybrid Renewable Energy System: Importance of data selection with highly variable renewable energy sources. Energy Convers. Manag. 2020, 223, 113303. [CrossRef]

22. Bunodiere, A.; Lee, H.S. Renewable Energy Curtailment: Prediction Using a Logic-Based Forecasting Method and Mitigation Measures in Kyushu, Japan. Energies 2020, 13, 4703. [CrossRef]

23. Park, J.; Moon, J.; Jung, S.; Hwang, E. Multistep-Ahead Solar Radiation Forecasting Scheme Based on the Light Gradient Boosting Machine: A Case Study of Jeju Island. Remote Sens. 2020, 12, 2271. [CrossRef]

24. Garni, H.Z.A.; Awasthi, A. Solar PV Power Plants Site Selection: A Review. In Advances in Renewable Energies and Power Technologies; Concordia Institute for Information Systems Engineering, Concordia University: Montreal, QC, Canada, 2018; pp. 57-75. [CrossRef]

25. Korkovelos, A.; Bazilian, M.; Mentis, D.; Howells, M. A GIS Approach to Planning Electrification in Afghanistan. Available online: https: / / openknowledge.worldbank.org/handle/10986/29140 (accessed on 18 March 2021).

26. Tyralis, H.; Mamassis, N.; Photis, Y.N. Spatial Analysis of Electrical Energy Demand Patterns in Greece: Application of a GIS-based Methodological Framework. Energy Procedia 2016, 97, 262-269. [CrossRef]

27. Yeo, I.-A.; Yoon, S.-H.; Yee, J.-J. Development of an Urban Energy Demand Forecasting System to Support Environmentally Friendly Urban Planning. Appl. Energy 2013, 110, 304-317. [CrossRef]

28. Santoli, L.D.; Mancini, F.; Garcia, D.A. A GIS-Based Model to Assess Electric Energy Consumptions and Usable Renewable Energy Potential in Lazio Region at Municipality Scale. Sustain. Cities Soc. 2019, 46, 101413. [CrossRef]

29. Zhang, Y.; Zhang, Y.; Yu, H.; Li, J.; Xie, Y.; Lei, Z. Geothermal Resource Potential Assessment of Fujian Province, China, Based on Geographic Information System (GIS) -Supported Models. Renew. Energy 2020, 153, 564-579. [CrossRef]

30. Xu, Y.; Li, Y.; Zheng, L.; Cui, L.; Li, S.; Li, W.; Cai, Y. Site Selection of Wind Farms Using GIS and Multi-Criteria Decision Making Method in Wafangdian, China. Energy 2020, 207, 118222. [CrossRef]

31. Đurišić, V.; Rogić, S.; Smolović, J.C.; Radonjić, M. Determinants of Household Electrical Energy Consumption: Evidences and Suggestions with Application to Montenegro. Energy Rep. 2020, 6, 209-217. [CrossRef]

32. Wang, Q.; M'Ikiugu, M.; Kinoshita, I. A GIS-Based Approach in Support of Spatial Planning for Renewable Energy: A Case Study of Fukushima, Japan. Sustainability 2014, 6, 2087-2117. [CrossRef]

33. Corigliano, S.; Carnovali, T.; Edeme, D.; Merlo, M. Holistic geospatial data-based procedure for electric network design and least-cost energy strategy. Energy Sustain. Dev. 2020, 58, 1-15. [CrossRef]

34. Bosisio, A.; Berizzi, A.; Amaldi, E.; Bovo, C.; Morotti, A.; Greco, B.; Iannarelli, G. A GIS-based Approach for High-Level Distribution Networks Expansion Planning in Normal and Contingency Operation Considering Reliability. Electr. Power Syst. Res. 2021, 190, 106684. [CrossRef]

35. Vasileiou, M.; Loukogeorgaki, E.; Vagiona, D.G. GIS-Based Multi-Criteria Decision Analysis for Site Selection of Hybrid Offshore Wind and Wave Energy Systems in Greece. Renew. Sustain. Energy Rev. 2017, 73, 745-757. [CrossRef]

36. Rogeau, A.; Girard, R.; Kariniotakis, G. A Generic GIS-based Mmethod for Small Pumped Hydro Energy Storage (PHES) Potential Evaluation at Large Scale. Appl. Energy 2017, 197, 241-253. [CrossRef]

37. Sun, L.; Jiang, Y.; Guo, Q.; Ji, L.; Xie, Y.; Qiao, Q.; Huang, G.; Xiao, K. A GIS-Based Multi-Criteria Decision Making Method for the Potential Assessment and Suitable Sites Selection of PV and CSP Plants. Resour. Conserv. Recycl. 2021, 168, 105306. [CrossRef]

38. Rikalovic, A.; Cosic, I.; Lazarevic, D. GIS Based Multi-criteria Analysis for Industrial Site Selection. Procedia Eng. 2014, 69, 1054-1063. [CrossRef]

39. Pojadas, D.J.; Abundo, M.L.S. A Spatial Cost-Benefit-Externality Modelling Framework for Siting of Variable Renewable Energy Farms: A Case in Bohol, Philippines. Renew. Energy 2022, 181, 1177-1187. [CrossRef]

40. Aly, A.; Jensen, S.S.; Pedersen, A.B. Solar Power Potential of Tanzania: Identifying CSP and PV Hot Spots Through a GIS Multicriteria Decision Making Analysis. Renew. Energy 2017, 113, 159-175. [CrossRef]

41. Tercan, E.; Eymen, A.; Urfalı, T.; Saracoglu, B.O. A Sustainable Framework for Spatial Planning of Photovoltaic Solar Farms using GIS and Multi-Criteria Assessment Approach in Central Anatolia, Turkey. Land Use Policy 2021, 102, 105272. [CrossRef]

42. Diemuodeke, E.O.; Addo, A.; Oko, C.O.C.; Mulugetta, Y.; Ojapah, M.M. Optimal Mapping of Hybrid Renewable Energy Systems for Locations Using Multi-Criteria Decision-Making Algorithm. Renew. Energy 2019, 134, 461-477. [CrossRef]

43. Cunden, T.S.M.; Doorga, J.; Lollchund, M.R.; Rughooputh, S.D.D.V. Multi-level Constraints Wind Farms Siting for a Complex Terrain in a Tropical Region using MCDM Approach Coupled with GIS. Energy 2020, 211, 118533. [CrossRef]

44. Ilbahar, E.; Cebi, S.; Kahraman, C. A State-of-the-Art Review on Multi-Attribute Renewable Energy Decision Making. Energy Strategy Rev. 2019, 25, 18-33. [CrossRef]

45. Saaty, T.L. The Analytic Hierarchy Process: Decision Making in Complex Environments. In Quantitative Assessment in Arms Control: Mathematical Modeling and Simulation in the Analysis of Arms Control Problems; Avenhaus, R., Huber, R.K., Eds.; Springer: Boston, MA, USA, 1984; pp. 285-308. [CrossRef]

46. Colak, H.E.; Memisoglu, T.; Gercek, Y. Optimal site selection for solar photovoltaic (PV) power plants using GIS and AHP: A case study of Malatya Province, Turkey. Renew. Energy 2020, 149, 565-576. [CrossRef] 
47. Chang, H.-K.; Liou, J.-C.; Chen, W.-W. Protection Priority in the Coastal Environment Using a Hybrid AHP-TOPSIS Method on the Miaoli Coast, Taiwan. J. Coast. Res. 2012, 28, 369-374. [CrossRef]

48. Ramya, S.; Devadas, V. Integration of GIS, AHP and TOPSIS in Evaluating Suitable Locations for Industrial Development: A Case of Tehri Garhwal District, Uttarakhand, India. J. Clean. Prod. 2019, 238, 117872. [CrossRef]

49. Konstantinos, I.; Georgios, T.; Garyfalos, A. A Decision Support System Methodology for Selecting Wind Farm Installation Locations using AHP and TOPSIS: Case Study in Eastern Macedonia and Thrace Region, Greece. Energy Policy 2019, 132, 232-246. [CrossRef]

50. Sindhu, S.; Nehra, V.; Luthra, S. Investigation of Feasibility Study of Solar Farms Deployment Using Hybrid AHP-TOPSIS Analysis: Case study of India. Renew. Sustain. Energy Rev. 2017, 73, 496-511. [CrossRef]

51. Jozaghi, A.; Alizadeh, B.; Hatami, M.; Flood, I.; Khorrami, M.; Khodaei, N.; Tousi, E.G. A Comparative Study of the AHP and TOPSIS Techniques for Dam Site Selection Using GIS: A Case Study of Sistan and Baluchestan Province, Iran. Geosciences 2018, 8, 494. [CrossRef]

52. Abdel-Basset, M.; Gamal, A.; Chakrabortty, R.K.; Ryan, M. A New Hybrid Multi-Criteria Decision-Making Approach for Location Selection of Sustainable Offshore Wind Energy Stations: A Case Study. J. Clean. Prod. 2021, 280, 124462. [CrossRef]

53. Lo, H.-W.; Hsu, C.-C.; Chen, B.-C.; Liou, J.J.H. Building a Grey-Based Multi-Criteria Decision-Making Model for Offshore Wind Farm Site Selection. Sustain. Energy Technol. Assess. 2021, 43, 100935. [CrossRef]

54. Gouareh, A.; Settou, B.; Settou, N. A New Geographical Information System Approach Based on Best Worst Method and Analytic Hierarchy Process for Site Suitability and Technical Potential Evaluation for Large-Scale CSP On-Grid Plant: An Application for Algeria Territory. Energy Convers. Manag. 2021, 235, 113963. [CrossRef]

55. Shorabeh, S.N.; Argany, M.; Rabiei, J.; Firozjaei, H.K.; Nematollahi, O. Potential Assessment of Multi-Renewable Energy Farms Establishment Using Spatial Multi-Criteria Decision Analysis: A Case Study and Mapping in Iran. J. Clean. Prod. 2021, $295,126318$. [CrossRef]

56. Şan, M.; Akpınar, A.; Bingölbali, B.; Kankal, M. Geo-Spatial Multi-Criteria Evaluation of Wave Energy Exploitation in a SemiEnclosed Sea. Energy 2021, 214, 118997. [CrossRef]

57. Potić, I.; Joksimović, T.; Milinčić, U.; Kićović, D.; Milinčić, M. Wind Energy Potential for the Electricity Production - Knjaževac Municipality Case Study (Serbia). Energy Strategy Rev. 2021, 33, 100589. [CrossRef]

58. Haddad, B.; Díaz-Cuevas, P.; Ferreira, P.; Djebli, A.; Pérez, J.P. Mapping Concentrated Solar Power Site Suitability in Algeria. Renew. Energy 2021, 168, 838-853. [CrossRef]

59. Lindberg, O.; Birging, A.; Widén, J.; Lingfors, D. PV Park Site Selection for Utility-Scale Solar Guides Combining GIS and Power Flow Analysis: A Case Study on a Swedish Municipality. Appl. Energy 2021, 282, 116086. [CrossRef]

60. Gkeka-Serpetsidaki, P.; Tsoutsos, T. 13-Sustainable Site Selection of offshore Wind Farms Using GIS-Based Multi-Criteria Decision Analysis and Analytical Hierarchy process. Case study: Island of Crete (Greece). In Low Carbon Energy Technologies in Sustainable Energy Systems; Kyriakopoulos, G.L., Ed.; Academic Press-Elsevier: Cambridge, MA, USA, 2021 ; pp. $329-342$.

61. Zambrano-Asanza, S.; Quiros-Tortos, J.; Franco, J.F. Optimal Site Selection for Photovoltaic Power Plants using a GIS-Based Multi-Criteria Decision Making and Spatial Overlay with Electric Load. Renew. Sustain. Energy Rev. 2021, 143, 110853. [CrossRef]

62. Meng, F.; Liang, X.; Xiao, C.; Wang, G. Geothermal Resource Potential Assessment Utilizing GIS-Based Multi Criteria Decision Analysis Method. Geothermics 2021, 89, 101969. [CrossRef]

63. Saraswat, S.K.; Digalwar, A.K.; Yadav, S.S.; Kumar, G. MCDM and GIS Based Modelling Technique for Assessment of Solar and Wind Farm Locations in India. Renew. Energy 2021, 169, 865-884. [CrossRef]

64. Abuzied, S.M.; Kaiser, M.F.; Shendi, E.-A.H.; Abdel-Fattah, M.I. Multi-Criteria Decision Support for Geothermal Resources Exploration Based on Remote Sensing, GIS and Geophysical Techniques Along the Gulf of Suez Coastal Area, Egypt. Geothermics 2020, 88, 101893. [CrossRef]

65. Dhiman, H.S.; Deb, D. Fuzzy TOPSIS and Fuzzy COPRAS Based Multi-Criteria Decision Making for Hybrid Wind Farms. Energy 2020, 202, 117755. [CrossRef]

66. Tamm, O.; Tamm, T. Verification of a Robust Method for Sizing and Siting the Small Hydropower Run-Of-River Plant Potential by using GIS. Renew. Energy 2020, 155, 153-159. [CrossRef]

67. Rezaei, M.; Khalilpour, K.R.; Jahangiri, M. Multi-Criteria Location Identification for Wind/Solar Based Hydrogen Generation: The Case of Capital Cities of a Developing Country. Int. J. Hydrogen Energy 2020, 45, 33151-33168. [CrossRef]

68. Tian, Y.; Zhang, F.; Yuan, Z.; Che, Z.; Zafetti, N. Assessment Power Generation Potential of Small Hydropower Plants using GIS Software. Energy Rep. 2020, 6, 1393-1404. [CrossRef]

69. Hassaan, M.A.; Hassan, A.; Al-Dashti, H. GIS-based Suitability Analysis for siting Solar Power Plants in Kuwait. Egypt. J. Remote Sens. Space Sci. 2021, 24, 453-461. [CrossRef]

70. Feng, J.; Feng, L.; Wang, J.; King, C.W. Evaluation of the onshore Wind Energy Potential in Mainland China-Based on GIS Modeling and EROI Analysis. Resour. Conserv. Recycl. 2020, 152, 104484. [CrossRef]

71. Fraia, S.D.; Fabozzi, S.; Macaluso, A.; Vanoli, L. Energy Potential of Residual Biomass from Agro-industry in a Mediterranean Region of Southern Italy (Campania). J. Clean. Prod. 2020, 277, 124085. [CrossRef]

72. Mensour, O.N.; Ghazzani, B.E.; Hlimi, B.; Ihlal, A. A geographical Information System-Based Multi-Criteria Method for the Evaluation of Solar Farms Locations: A Case Study in Souss-Massa Area, Southern Morocco. Energy 2019, 182, 900-919. [CrossRef] 
73. Mutombo, N.M.-A.; Numbi, B.P. Assessment of Renewable Energy Potential in Kwazulu-Natal Province, South Africa. Energy Rep. 2019, 5, 874-881. [CrossRef]

74. Shorabeh, S.N.; Firozjaei, M.K.; Nematollahi, O.; Firozjaei, H.K.; Jelokhani-Niaraki, M. A Risk-Based Multi-Criteria Spatial Decision Analysis for Solar Power Plant Site Selection in Different Climates: A Case Study in Iran. Renew. Energy 2019, 143, 958-973. [CrossRef]

75. Sliz-Szkliniarz, B.; Eberbach, J.; Hoffmann, B.; Fortin, M. Assessing the Cost of onshore Wind Development Scenarios: Modelling of Spatial and Temporal Distribution of Wind Power for the Case of Poland. Renew. Sustain. Energy Rev. 2019, 109, 514-531. [CrossRef]

76. Laasasenaho, K.; Lensu, A.; Lauhanen, R.; Rintala, J. GIS-Data Related Route Optimization, Hierarchical Clustering, Location Optimization, and Kernel Density Methods are Useful for Promoting Distributed Bioenergy Plant Planning in Rural Areas. Sustain. Energy Technol. Assess. 2019, 32, 47-57. [CrossRef]

77. Vavatsikos, A.P.; Arvanitidou, A.; Petsas, D. Wind Farm Investments Portfolio Formation Using Gis-Based Suitability Analysis and Simulation Procedures. J. Environ. Manag. 2019, 252, 109670. [CrossRef]

78. Messaoudi, D.; Settou, N.; Negrou, B.; Settou, B. GIS Based Multi-Criteria Decision Making for Solar Hydrogen Production Sites Selection in Algeria. Int. J. Hydrogen Energy 2019, 44, 31808-31831. [CrossRef]

79. Solangi, Y.A.; Shah, S.A.A.; Zameer, H.; Ikram, M.; Saracoglu, B.O. Assessing the Solar PV Power Project Site Selection in Pakistan: Based on AHP-Fuzzy VIKOR Approach. Environ. Sci. Pollut. Res. 2019, 26, 30286-30302. [CrossRef]

80. Ghasemi, G.; Noorollahi, Y.; Alavi, H.; Marzband, M.; Shahbazi, M. Theoretical and Technical Potential Evaluation of Solar Power Generation in Iran. Renew. Energy 2019, 138, 1250-1261. [CrossRef]

81. Nematollahi, O.; Alamdari, P.; Jahangiri, M.; Sedaghat, A.; Alemrajabi, A.A. A Techno-Economical Assessment of Solar/Wind Resources and Hydrogen Production: A Case Study With GIS Maps. Energy 2019, 175, 914-930. [CrossRef]

82. Ali, S.; Taweekun, J.; Techato, K.; Waewsak, J.; Gyawali, S. GIS Based Site Suitability Assessment for Wind and Solar Farms in Songkhla, Thailand. Renew. Energy 2019, 132, 1360-1372. [CrossRef]

83. Rezaei, M.; Mostafaeipour, A.; Qolipour, M.; Tavakkoli-Moghaddam, R. Investigation of the Optimal Location Design of a Hybrid Wind-Solar Plant: A Case Study. Int. J. Hydrogen Energy 2018, 43, 100-114. [CrossRef]

84. Zaidi, A.Z.; Khan, M. Identifying High Potential Locations for Run-of-the-River Hydroelectric Power Plants using GIS and Digital Elevation Models. Renew. Sustain. Energy Rev. 2018, 89, 106-116. [CrossRef]

85. Ayodele, T.R.; Ogunjuyigbe, A.S.O.; Odigie, O.; Munda, J.L. A Multi-Criteria GIS Based Model for Wind Farm Site Selection Using Interval Type-2 Fuzzy Analytic Hierarchy Process: The Case Study of Nigeria. Appl. Energy 2018, 228, 1853-1869. [CrossRef]

86. Nie, B.; Li, J. Technical Potential Assessment of Offshore Wind Energy over Shallow Continent Shelf Along China Coast. Renew. Energy 2018, 128, 391-399. [CrossRef]

87. Garegnani, G.; Sacchelli, S.; Balest, J.; Zambelli, P. GIS-Based Approach for Assessing the Energy Potential and the financial Feasibility of Run-Off-River Hydro-Power in Alpine Valleys. Appl. Energy 2018, 216, 709-723. [CrossRef]

88. Huang, T.; Wang, S.; Yang, Q.; Li, J. A GIS-Based Assessment of large-Scale PV Potential in China. Energy Procedia 2018, 152, 1079-1084. [CrossRef]

89. Zaher, M.A.; Elbarbary, S.; El-Shahat, A.; Mesbah, H.; Embaby, A. Geothermal Resources in Egypt Integrated with GIS-Based Analysis. J. Volcanol. Geotherm. Res. 2018, 365, 1-12. [CrossRef]

90. Yushchenko, A.; Bono, A.D.; Chatenoux, B.; Patel, M.K.; Ray, N. GIS-based Assessment of Photovoltaic (PV) and Concentrated Solar Power (CSP) Generation Potential in West Africa. Renew. Sustain. Energy Rev. 2018, 81, 2088-2103. [CrossRef]

91. Turk, S.; Sahin, G. Multi-Criteria Decision-Making in the Location Selection for a Solar PV Power Plant using AHP. Measurement 2018, 129, 218-226.

92. Merrouni, A.A.; Elalaoui, F.E.; Ghennioui, A.; Mezrhab, A.; Mezrhab, A. A GIS-AHP Combination for the Sites Assessment of Large-Scale CSP Plants with Dry and Wet Cooling Systems. Case Study: Eastern Morocco. Sol. Energy 2018, 166, 2-12. [CrossRef]

93. Zyadin, A.; Natarajan, K.; Latva-Käyrä, P.; Igliński, B.; Iglińska, A.; Trishkin, M.; Pelkonen, P.; Pappinen, A. Estimation of Surplus Biomass Potential in Southern and Central Poland Using GIS Applications. Renew. Sustain. Energy Rev. 2018, 89, 204-215. [CrossRef]

94. Yousefi, H.; Noorollahi, Y.; Hajinezhad, A.; Alimohammadi, A. GIS-Based Spatially Integrated Bioenergy Resources Assessment in Kurdistan Province-Northwest Iran. Sustain. Energy Technol. Assess. 2017, 23, 11-20. [CrossRef]

95. Noorollahi, Y.; Arjenaki, H.G.; Ghasempour, R. Thermo-Economic Modeling and GIS-Based Spatial Data Analysis of Ground Source Heat Pump Systems for Regional Shallow Geothermal Mapping. Renew. Sustain. Energy Rev. 2017, 72, 648-660. [CrossRef]

96. Bayazıt, Y.; Bakış, R.; Koç, C. An Investigation of Small Scale Hydropower Plants Using the Geographic Information System. Renew. Sustain. Energy Rev. 2017, 67, 289-294. [CrossRef]

97. Kausika, B.B.; Dolla, O.; Sark, W.G.J.H.M.v. Assessment of Policy Based Residential Solar PV Potential Using GIS-based Multicriteria Decision Analysis: A Case Study of Apeldoorn, The Netherlands. Energy Procedia 2017, 134, 110-120. [CrossRef]

98. Soha, T.; Munkácsy, B.; Harmat, Á.; Csontos, C.; Horváth, G.; Tamás, L.; Csüllög, G.; Daróczi, H.; Sáfián, F.; Szabó, M. GIS-Based Assessment of the Opportunities for small-Scale Pumped Hydro Energy Storage in Middle-Mountain Areas Focusing on Artificial Landscape Features. Energy 2017, 141, 1363-1373. [CrossRef]

99. Ketzer, D.; Rösch, C.; Haase, M. Assessment of Sustainable Grassland Biomass Potentials for Energy Supply in Northwest Europe. Biomass Bioenergy 2017, 100, 39-51. [CrossRef]

100. IEA. Solar PV. Available online: https:/ /www.iea.org/reports/solar-pv (accessed on 29 March 2021). 
101. Schallenberg-Rodríguez, J.; Montesdeoca, N.G. Spatial Planning to Estimate the Offshore Wind Energy Potential in Coastal Regions and Islands. Practical Case: The Canary Islands. Energy 2018, 143, 91-103. [CrossRef]

102. PhilAtlas. Cuyo: Province of Palawan. Available online: https://www.philatlas.com/luzon/mimaropa/palawan/cuyo.html (accessed on 3 November 2019).

103. PhilAtlas. Palawan. Available online: https://www.philatlas.com/luzon/mimaropa/palawan.html (accessed on 3 November 2019).

104. Philippine Statistics Authority. Housing Characteristics in the Philippines (Results of the 2015 Census of Population). Available online: https:/ / psa.gov.ph/population-and-housing/node/129804 (accessed on 14 October 2019).

105. Majumdar, D.; Pasqualetti, M.J. Analysis of Land Availability for Utility-Scale Power Plants and Assessment of Solar Photovoltaic Development in the State of Arizona, USA. Renew. Energy 2019, 134, 1213-1231. [CrossRef]

106. Charabi, Y.; Gastli, A. PV Site Suitability Analysis Using Gis-Based Spatial Fuzzy Multi-Criteria Evaluation. Renew. Energy 2011, 36, 2554-2561. [CrossRef]

107. Al-Shammari, S.; Ko, W.; Ammar, E.A.A.; Alotaibi, M.A.; Choi, H.-J. Optimal Decision-Making in Photovoltaic System Selection in Saudi Arabia. Energies 2021, 14, 357. [CrossRef]

108. Munkhbat, U.; Choi, Y. GIS-Based Site Suitability Analysis for Solar Power Systems in Mongolia. Appl. Sci. 2021, 11, 3748. [CrossRef]

109. Global Wind Atlas 3.0. Available online: https:/ / globalwindatlas.info/ (accessed on 3 October 2021).

110. Tulang, A.B.; Bello, A.Q. Forecasting Power Load Demand Using Holt-Winters Model. Int. J. Educ. Res. High. Learn. 2018, $24,115-124$.

111. Albraheem, L.; Alabdulkarim, L. Geospatial Analysis of Solar Energy in Riyadh Using a GIS-AHP-Based Technique. ISPRS Int. J. Geo-Inf. 2021, 10, 291. [CrossRef]

112. USEPA (United States Environmental Protection Agency). Data Documentation for Mapping and Screening Criteria for Renewable Energy Generation Potential on EPA and State Tracked Sites RE-Powering America's Land Initiative. Available online: https:/ / www.epa.gov/sites/default/files/2015-04/documents/repowering_mapper_datadocumentation.pdf (accessed on 3 October 2021).

113. Nebey, A.H.; Taye, B.Z.; Workineh, T.G. Site Suitability Analysis of Solar PV Power Generation in South Gondar, Amhara Region. J. Energy 2020, 2020, 3519257. [CrossRef]

114. Anwarzai, M.A.; Nagasaka, K. Utility-Scale Implementable Potential of Wind and Solar Energies for Afghanistan using GIS Multi-Criteria Decision Analysis. Renew. Sustain. Energy Rev. 2017, 71, 150-160. [CrossRef]

115. Pojadas, D.J.; Abundo, M.L.S. Spatio-Temporal Assessment and Economic Analysis of a Grid-Connected Island Province Toward a 35\% or Greater Domestic Renewable Energy Portfolio: A Case in Bohol, Philippines. Int. J. Energy Environ. Eng. 2021, 12, 251-280. [CrossRef]

116. Bina, S.M.; Jalilinasrabady, S.; Fujii, H.; Farabi-Asl, H. A Comprehensive Approach for Wind Power Plant Potential Assessment, Application to Northwestern Iran. Energy 2018, 164, 344-358. [CrossRef]

117. Piirisaar, I. A Multi-Criteria GIS Analysis for Siting of Utility-Scale Photovoltaic Solar Plants in County Kilkenny, Ireland. Master's Thesis, Geographical Information Science, Lund University, Lund, Sweden, 2019.

118. Lozano-García, D.F.; Santibañez-Aguilar, J.E.; Lozano, F.J.; Flores-Tlacuahuac, A. GIS-based Modeling of Residual Biomass Availability for Energy and Production in Mexico. Renew. Sustain. Energy Rev. 2020, 120, 109610. [CrossRef]

119. Ghose, D.; Naskar, S.; Shabbiruddin; Sadeghzadeh, M.; Assad, M.E.H.; Nabipour, N. Siting High Solar Potential Areas using Q-GIS in West Bengal, India. Sustain. Energy Technol. Assess. 2020, 42, 100864. [CrossRef]

120. Díaz-Cuevas, P.; Domínguez-Bravo, J.; Prieto-Campos, A. Integrating MCDM and GIS for Renewable Energy Spatial Models: Assessing the Individual and Combined Potential for Wind, Solar and Biomass Energy in Southern Spain. Clean Technol. Environ. Policy 2019, 21, 1855-1869. [CrossRef]

121. Gašparović, I.; Gašparović, M. Determining Optimal Solar Power Plant Locations Based on Remote Sensing and GIS Methods: A Case Study from Croatia. Remote Sens. 2019, 11, 1481. [CrossRef]

122. Messaoudi, D.; Settou, N.; Negrou, B.; Rahmouni, S.; Settou, B.; Mayou, I. Site Selection Methodology for the Wind-Powered Hydrogen Refueling Station Based on AHP-GIS in Adrar, Algeria. Energy Procedia 2019, 162, 67-76. [CrossRef]

123. Asakereh, A.; Soleymani, M.; Sheikhdavoodi, M.J. A GIS-Based Fuzzy-AHP Method for the Evaluation of Solar Farms Locations: Case Study in Khuzestan Province, Iran. Sol. Energy 2017, 155, 342-353. [CrossRef]

124. Zahid, F.; Tahir, A.; Khan, H.U.; Naeem, M.A. Wind Farms Selection Using Geospatial Technologies and Energy Generation Capacity in Gwadar. Energy Rep. 2021, 7, 5857-5870. [CrossRef]

125. Giamalaki, M.; Tsoutsos, T. Sustainable Siting of Solar Power Installations in Mediterranean using a GIS/AHP Approach. Renew. Energy 2019, 141, 64-75. [CrossRef]

126. Sun, Y.-W.; Hof, A.; Wang, R.; Liu, J.; Lin, Y.-J.; Yang, D.-W. GIS-based Approach for Potential Analysis of Solar PV Generation at the Regional Scale: A Case Study of Fujian Province. Energy Policy 2013, 58, 248-259. [CrossRef]

127. Aydin, N.Y.; Kentel, E.; Duzgun, H.S. GIS-based Site Selection Methodology for Hybrid Renewable Energy Systems: A Case Study from Western Turkey. Energy Convers. Manag. 2013, 70, 90-106. [CrossRef]

128. Villacreses, G.; Gaona, G.; Martínez-Gómez, J.; Jijón, D.J. Wind Farms Suitability Location Using Geographical Information System (GIS), Based on Multi-Criteria Decision making (MCDM) methods: The Case of Continental Ecuador. Renew. Energy 2017, 109, 275-286. [CrossRef] 
129. Baseer, M.A.; Rehman, S.; Meyer, J.P.; Alam, M.M. GIS-based site suitability analysis for wind farm development in Saudi Arabia. Energy 2017, 141, 1166-1176. [CrossRef]

130. Shah, S.A.A.; Solangi, Y.A.; Ikram, M. Analysis of Barriers to the Adoption of Cleaner Energy Technologies in Pakistan using Modified Delphi and Fuzzy Analytical Hierarchy Process. J. Clean. Prod. 2019, 235, 1037-1050. [CrossRef]

131. Sánchez-Lozano, J.M.; García-Cascales, M.S.; Espinosa, N.; Urbina, A. Application of the AHP and TOPSIS Methods to the Assessment of Photovoltaic Technologies; Cambridge Scholars Publishing: Newcastle upon Tyne, UK, 2016; pp. 58-75.

132. Zadeh, L.A. Fuzzy sets. Inf. Control 1965, 8, 338-353. [CrossRef]

133. Putra, M.S.D.; Andryana, S.; Fauziah; Gunaryati, A. Fuzzy Analytical Hierarchy Process Method to Determine the Quality of Gemstones. Adv. Fuzzy Syst. 2018, 2018, 9094380. [CrossRef]

134. Hapsari, M.A.; Subiyanto, S. Fuzzy AHP Based Optimal Design Building-Attached Photovoltaic System for Academic Campus. Int. J. Photoenergy 2020, 2020, 6508329. [CrossRef]

135. Hwang, C.L.; Yoon, K. Multiple Attribute Decision Making: Methods and Applications: A State-of-the-Art Survey; Springer: Berlin, Germany; New York, NY, USA, 1981.

136. Ghorbani, N.; Makian, H.; Breyer, C. A GIS-based Method to Identify Potential Sites for Pumped Hydro Energy Storage-Case of Iran. Energy 2019, 169, 854-867. [CrossRef]

137. Kengpol, A.; Rontlaong, P.; Tuominen, M. A Decision Support System for Selection of Solar Power Plant Locations by Applying Fuzzy AHP and TOPSIS: An Empirical Study. J. Softw. Eng. Appl. 2013, 6, 470-481. [CrossRef]

138. Department of Energy. Biomass, Solar, Wind and Ocean. Available online: https://www.doe.gov.ph/biomass-solar-wind-andocean (accessed on 30 August 2021).

139. The World Bank Group. Global Solar Atlas. Available online: https://globalsolaratlas.info/map (accessed on 19 September 2021).

140. Sotiropoulou, K.F.; Vavatsikos, A.P. Onshore Wind Farms GIS-Assisted Suitability Analysis Using PROMETHEE II. Energy Policy 2021, 158, 112531. [CrossRef]

141. International Finance Corporation: World Bank Group. Utility-Scale Solar Photovoltaic Power Plants: A Projects Developer's Guide. Available online: https://www.ifc.org/wps/wcm/connect/a1b3dbd3-983e-4ee3-a67b-cdc29ef900cb/IFC+Solar+Report_ Web+_08+05.pdf?MOD=AJPERES\&CVID=kZePDPG (accessed on 14 October 2021).

142. New Zealand Energy Association. Considering a Wind Farm on Your Land? Available online: https://www.windenergy.org.nz/ store/doc/Considering_a_wind_farm.pdf (accessed on 9 October 2021). 